
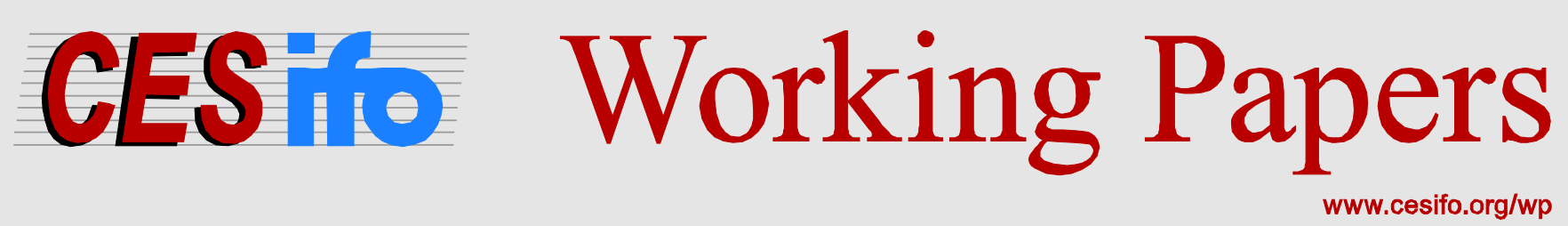

\title{
Partisan Politics: \\ The Empirical Evidence from OECD Panel Studies
}

\author{
Niklas Potrafke
}

CESIFO WORKING PAPER NO. 6024

CATEGORY 2: PUBliC CHOICE

JULY 2016

An electronic version of the paper may be downloaded

- from the SSRN website: Www.SSRN.com

- from the RePEc website: Www.RePEc.org

- from the CESifo website: www.CESifo-group.org/wp 


\title{
Partisan Politics: The Empirical Evidence from OECD Panel Studies
}

\begin{abstract}
This paper describes the empirical evidence on partisan politics in OECD panel studies. I elaborate on the research designs, the measurement of government ideology and why the empirical studies do not and cannot derive causal effects. Discussing about 100 panel data studies, the results indicate that leftwing and rightwing governments pursued different economic policies until the 1990s: the size and scope of government was larger when leftwing governments were in power. Partisan politics have not disappeared since the 1990s, but have certainly become less pronounced. In particular, government ideology still seems to influence policies such as privatization and market deregulation. I discuss the consequences of declining electoral cohesion and what future research needs to explore.
\end{abstract}

JEL-Codes: D720, H000, C230.

Keywords: partisan politics, government ideology, economic policy-making, declining electoral cohesion, panel data models, causal effects.

\author{
Niklas Potrafke \\ Ifo Institute - Leibniz Institute for \\ Economic Research \\ at the University of Munich \\ Poschingerstrasse 5 \\ Germany-81679 Munich \\ potrafke@ifo.de
}

21 July 2016

I am grateful for comments from Christian Bjørnskov, Jörg Breitung, Marius Busemeyer, Vitor Castro, Chun-Ping Chang, Marc Debus, Georgios Efthyvoulou, Ronny Freier, Sebastian Garmann, Douglas Hibbs, Kai Jäger, Carsten Jensen, Bernhard Kittel, Florian Neumeier, Christoph Schinke, Carina Schmitt, Markus Tepe, and Heinrich Ursprung and Lisa GianiContini for proof-reading. Lena Sophie Müller and Kristin Fischer have provided excellent research assistance. 


\section{Introduction}

The question of whether government ideology influences economic policy-making has been debated for many years. The partisan theories predict that leftwing governments pursue more expansionary policies than rightwing governments. In the 1980s and 1990s, many empirical studies have shown evidence of ideology-induced policy-making. Government ideology is expected to have an influence because political parties gratify the needs of their constituencies. Leftwing parties have received a great deal of electoral support from working class and low-income voters. After the end of the Cold War and the fall of the Iron Curtain, however, electoral cohesion declined and party positions moved. Government ideology retired to the background.

The financial crisis that began in 2007 and growing income inequality gave rise to criticism of capitalism in industrialized countries. Advocates of a large size and scope of government used this window of opportunity to further denigrate the functioning of markets. Advocates of a limited government, by contrast, did not arrive at the conclusion that governments' responsibilities should be enlarged in general because of the instability afflicting a specific market (the financial market). Political parties thus once again exhibited diverging political platforms. In the United States, for example, political polarization between Democrats and Republicans increased.

Why does empirical evidence on partisan politics deserve attention? I propose three reasons. Firstly, when government ideology influences economic policies, economic agents will change their behavior according to the economic policies that the new government is expected to pursue. If voters predict, for example, that a leftwing government will succeed a rightwing government, they will expect increases in taxes and government expenditure, as well as stricter employment protection. Firms may then well postpone investment decisions. Stock and shareholders may also reshuffle their portfolios as a result of stock market reactions to changes in governments. On the one hand, the stock prices of firms in the defense and 
pharmaceutical sector are expected to increase whenever rightwing parties are likely to win the upcoming election. On the other hand, the stock prices of alternative energy firms are likely to increase when leftwing, and especially green parties, are about to take office. ${ }^{2}$ In such cases economic forecasters need to recalibrate their models that predict business cycles, tax revenues and the composition of the budget. Secondly, disenchantment with politics is an issue in industrialized countries. People turn away from politics because, for example, they believe politicians to be corrupt and lackadaisical. If political parties no longer matter, this tends to exacerbate disenchantment with politics. Thirdly, in representative democracies, people discuss introducing more direct democracy, for example, by holding referenda. When voters in representative democracies have manifold preferences, but parties do not manage to transmit voters’ manifold preferences, direct democratic institutions become more attractive.

Experts have surveyed the empirical literature on political business and budget cycles. ${ }^{3}$ Since Hibbs (1992), however, there has been no study surveying the empirical evidence on partisan politics in detail. Franzese and Jusko (2006) describe studies on partisan politics with a focus on comparing the traditional and rational partisan theory. Imbeau et al. (2001) performed a meta-analysis using 43 studies. I discuss the empirical evidence on partisan politics with a focus on OECD countries because most empirical studies use data for OECD countries and as compared to developing countries, data quality on macroeconomic variables etc. is much better and reliable government ideology indicators are available.

The partisan approach has been applied to many policy fields. Scholars have employed cross-country panel data, panel data for federal states such as the United States, Germany and Switzerland, and univariate time series in single country studies. Ideology-induced effects differ across countries and depend on the policy field in question. Studies for federal states

\footnotetext{
${ }^{2}$ For empirical evidence based on German stock market data, see Bechtel and Füss (2010). In the United States, by contrast, stock market performance was better overall under democratic administrations than under their republican counterparts (Hibbs 1994 and Blinder and Watson 2016).

${ }^{3}$ Surveys include Dubois (2016), De Haan and Klomp (2013), Alt and Rose (2009), Franzese and Jusko (2006). Cazals and Mandon (2015) do a meta-analysis. On political business and budget cycle theories, see Nordhaus (1975), Rogoff and Sibert (1988), Rogoff (1990). Downs (1957) on the median voter model.
} 
also elaborate on divided government (Alesina and Rosenthal 1995, 1996). Using local government data, in particular, experts derive causal effects on how government ideology influences economic policies. Regression discontinuity designs (RDD) are employed. However, deriving causal effects on how government ideology influences economic policymaking remains a critical issue in empirical research on partisan politics. When experts use panel data for OECD countries, for example, RDD is not suitable because datasets are too small.

I discuss around 100 OECD panel data studies. Section 2 describes the theoretical background on partisan politics, Section 3 describes the research designs of the empirical studies and Section 4 describes the policies pursued by individual policy fields. The main text focuses on studies that use government ideology as main explanatory variable. Table 1 includes the studies discussed in Section 4 and other studies indicating which dependent variable and government ideology measure was used, the effect of government ideology, the number of countries included and the period covered. Section 5 offers some conclusions.

\section{Theoretical Background}

The partisan theories describe how leftwing and rightwing politicians provide policies that reflect the preferences of their partisans. ${ }^{4}$ Leftist parties appeal more to their labor base and promote expansionary policies, whereas rightwing parties attract capital owners, and are therefore more concerned with reducing inflation. The partisan approaches assume that the economy can be described by a (short-run) Phillips-Curve-tradeoff; and that politicians are able to exploit the tradeoff strategically by fiscal and monetary policies. With respect to shortterm economic performance, the partisan models provide clear-cut predictions: leftist parties seek (or will accept) higher rates of inflation to obtain lower unemployment and faster

\footnotetext{
${ }^{4}$ Political scientists often use the term “parties-do-matter-hypothesis” (Schmidt 1996, 2002).
} 
growth; rightwing parties seek (or will tolerate) higher unemployment and slower growth to obtain lower inflation. This basic pattern holds for both the classical partisan approach (Hibbs 1977) and the rational one (Alesina 1987, Chappell and Keech 1986). The traditional partisan theory (PT) predicts government ideology’s permanent influence on economic policy-making. By contrast, Alesina et al. (1997: 62, Table 3.3) describe the empirical implications of the rational partisan theory (RPT) as follows: “1. Growth is temporarily higher, unemployment temporarily lower than the natural rate after a left-wing electoral victory; the opposite is true after a right-wing electoral victory. 2. Deviation of growth and unemployment from natural rates is correlated with the amount of electoral surprise. 3. Unemployment and growth return to their natural rates in the second part of both right- and left-wing terms of office. 4 . Inflation permanently higher when the left is in office.” The RPT does not predict that partisanpreferences change in the course of a legislative period. For a model considering that partisan objectives are revised in the light of experience, see Hibbs (1994). Hibbs (2006a: 671) writes: "These so-called "rational partisan theory" setups rested on the hypothesis that monetary (inflation) surprises created by unanticipated election victories by parties with divergent macroeconomic objectives were the source of partisan effects on output and unemployment observed in data.”

Political ideology notwithstanding, leftwing and rightwing incumbents are likely to pursue expansionary policies before elections, especially when the polls suggest that the opposition has good chances of winning the elections (Frey and Schneider 1978a, b).

The baseline partisan approach has been transferred to several policy fields. Many studies examining the effect of government ideology on an economic policy variable (at least the more recent ones) do not put an emphasis on disentangling the PT and the RPT. The core hypothesis to be tested in empirical research is:

Leftwing governments pursue more expansionary policies than rightwing governments. 
The partisan approaches were motivated by two-party systems (United States, United Kingdom etc.). Applying the partisan approaches to continental European countries that have a more heterogeneous party landscape, however, is also possible because, for many years and in many countries, leftwing and rightwing parties formed leftwing and rightwing coalitions (in Germany, for example, the conservative CDU/CSU and the market-oriented FDP formed rightwing coalitions, and the social democratic SPD and the environmentalist Green party formed leftwing coalitions). In the course of declining electoral cohesion and shifting party platforms, new theoretical approaches are needed to portray ideology-induced economic policy-making in multi-party systems. The coalition formation process needs to be considered; especially when a leftwing and a rightwing party are likely to form a grand coalition. ${ }^{5}$

\section{Research design}

\subsection{Baseline econometric model}

The baseline research design of the cross-country panel data studies is to regress a dependent variable Y (e.g., annual GDP growth, unemployment rates, inflation, tax rates, budget deficits, indicators to measure privatization in country $\mathrm{i}$ and year t) on (a) variable(s) that measure government ideology (e.g., dummy variables for leftwing governments or government ideology indices) and some control variables. Scholars estimate pooled panel data models or include fixed country effects and or fixed time effects. Econometric issues to be discussed are whether the dependent variables are stationary in levels. To avoid spurious regression when the dependent variables are not stationary in levels, some scholars use the outcome variable in first differences or growth rates. Experts usually discuss econometric issues such as serial correlation or the heteroskedasticity of the error terms. To what extent one may well arrive at

\footnotetext{
${ }^{5}$ For studies on coalition governments of leftwing and rightwing parties, see, for example, Helm and Neugart (2013)
} 
wrong conclusions when econometric models are not well specified has been discussed, for example, by Kittel and Winner (2005) and Plümper et al. (2005).

The panel data studies mostly include around 20 OECD countries. There have been 23 established OECD countries for which government ideology can be measured since the 1970s: Australia, Austria, Belgium, Canada, Denmark, Finland, France, Germany, Greece, Iceland, Ireland, Italy, Japan, Luxembourg, Netherlands, New Zealand, Norway, Portugal, Spain, Sweden, Switzerland, United Kingdom, and United States.

The OECD writes: “On 14 December 1960, 20 countries originally signed the Convention on the Organisation for Economic Co-operation and Development. Since then, 14 countries have become members of the Organisation.”6 Studies using panel data for OECD countries since the 2000s often include more than the 23 established countries (and are often unbalanced - meaning that there are data for some countries for many decades and for younger OECD member states just for some years).

Many of the OECD panel data studies include fixed country effects to deal with unobserved heterogeneity and assume that all other parameters are identical across countries. Scholars do not make an attempt to discuss and test individual specific parameters (see for example, Breitung 2015 on pooled versus individual specific parameters and Kittel 2006 for reflecting the extent to which estimating panel data models is useful in examining issues such as partisan politics).

\subsection{Measuring government ideology}

An important question is how to measure government ideology in OECD countries. A simple way to do so is to use a dummy variable for a leftwing or rightwing government. How should one identify a leftwing or rightwing government? For quite a few OECD countries, especially countries with two-party systems, distinguishing between leftwing and rightwing

\footnotetext{
${ }^{6}$ http://www.oecd.org/about/membersandpartners/list-oecd-member-countries.htm (accessed 29 April 2016).
} 
parties/governments is straightforward. In the United States and United Kingdom, for example, the Democrats and Labor are leftwing, while the Republicans and Tories are rightwing. Scholars mostly consider party families such as Social Democrats, Christian Democrats, Liberal Democrats etc. and the party family approach helps to distinguish between leftwing and rightwing parties. Information on leftwing and rightwing governments/parties is found, for example, in the Database of Political Institutions (DPI). The reference is Beck et al. (2001).

Scholars often use government ideology indicators on a left-right-scale, assuming values from 1 (extreme rightwing) to 5 (extreme leftwing). A case in point is the indicator by Budge et al. (1993) and Woldendorp et al. (1998, 2000). This index places the cabinet on a left-right scale with values between 1 and 5 . It takes the value 1 if the share of governing rightwing parties in terms of seats in the cabinet and in parliament is larger than $2 / 3$, and 2 if it is between $1 / 3$ and $2 / 3$. The index is 3 if the share of center parties is $50 \%$, or if the leftwing and rightwing parties form a coalition government not dominated by one side or the other. The index is symmetrical and takes the values 4 and 5 if the leftwing parties dominate.

I started to self-compile government ideology data based on the concept of Budge et al. (1993) and Woldendoorp et al. (1998, 2000) when I discovered codings I did not understand (or may merely have been erroneous). A prime example was the Grand coalition of the Christian Democratic Union (CDU) and the Social Democratic Union (SPD) - which used to be Germany’s major rightwing and leftwing parties for many decades (I will return to changes in the party systems below). This government with a Christian-Conservative chancellor was coded as 4 (leftwing government). I thought this government would have needed to be coded as 3 (center government). Adopting the classification by Budge et al. (1993) and Woldendorp et al. (1998, 2000), I constructed an ideology index for the 20 examined countries in Potrafke (2009a) over the period from 1980 to 2003. However, my coding explicitly refers to the left-right scale of the parties in an individual country. This 
indicator is consistent across time, but does not attempt to capture differences between the party-families across countries. The years in which the government changed are labeled according to the government that was in office for a longer period, e.g. when a rightwing government followed a leftwing government in August, I label this year as leftwing.

An important source of errors when coding government ideology is the years in which government changes. When using annual data, the most frequently described rule to code governments in which governments change is that an individual year will belong to the government that was in power for at least six months. When elections take place in the first half of a year, one may be tempted to code the individual year belonging to the new government. The coding goes wrong, however, when forming a new government lasts for some months and the new governments comes into power, for example, in September or October.

A database that is very often used and also employs the coding from 1 to 5 is the Comparative Political Dataset by Klaus Armingeon and collaborators (the current version is Armingeon et al. 2015). There is also an index by Manfred G. Schmidt and co-authors with a very similar coding.

To distinguish between ideologies of individual parties, there are expert surveys (Castles and Mair 1984, Warwick 1994). When parties are classified to be leftwing, center or rightwing, scholars often use the share of cabinet seats (or the parliamentary seats of the governing parties) to be weighted by scores of leftwing/rightwing parties. A prime example is Thomas Cusack’s (1997, 1999, 2001) center of gravity (CoG) measure, which weights the cabinet seats of individual parties by the parties’ positions based on a left-right scale (Castles and Mair 1984).

Bjørnskov’s (2008) index “takes the social democrat party in a given country as an internationally comparable anchor around which other parties are placed on a five-point scale $(-1 ;-.5 ; 0 ; .5 ; 1)$ from left to right” (p. 5). The index stresses the potential importance of the 
domestic political environment, and particularly whether governments have a majority in parliament or not.

Because parties readjust their positions, other experts use indicators based on party manifestos / platforms to capture this kind of strategic repositioning over time. These indices are based on the Comparative Manifesto Project (CMP) of Budge et al. (2001), Klingemann et al. (2006), and Volkens et al. (2014). The CMP data are based on content analysis of party platforms and include ideological scores of political parties in national parliaments since the end of the Second World War. As the scores are based on manifestos prepared for national elections, they vary by legislative periods and not by years. The basic CMP score measures parties' positions on a left-right (L-R) dimension. There are scores available for many individual policy fields such as the welfare state, market regulation, environmental protection etc. To measure government ideology based on the CMP data, scholars use the scores of the individual parties in government (weighted with each government party's relative share of all government party seats in parliament). The weighted government ideology measures based on the CMP data assume negative values for leftwing governments and positive values for rightwing governments. Criticism of the CMP data encompasses, for example, electoral motives: politicians may well design manifestos to become (re-)elected. It is conceivable that manifestos thus do not describe pure ideology (Gemenis 2013).

There is mixed evidence showing to what extent the choice of indicators measuring government ideology does (not) change the inferences. I conjecture that empirical studies using the CMP data are more likely to conclude that measuring government ideology makes a difference when political scientists executed the studies than when economists did.

Scholars also examine whether "left-labor power" influences economic policies (e. g., Garrett 1998, Clark 2003). "Left-labor power" combines the strength of leftwing parties in government and the legislature and the structure of trade union movements. I do not consider the effect of "Left-labor power". 


\subsection{Endogeneity}

The OECD panel data studies on ideology-induced economic policies do not identify causal effects. The government ideology variable is not exogenous. Many studies acknowledge that the government ideology variable is not exogenous. The reasons for endogeneity of the government ideology variables are reverse causality and omitted variables.

Reverse causality concerns arise because voters may not re-elect governments, when they disagree with the implemented policies (that are measured by the dependent variable). It is very possible that policies today influence which party will be in power tomorrow (see also the economic voting literature such as Lewis-Beck and Stegmaier 2013 and Hibbs 2006b). A strategy for circumventing the reverse causality concern and identifying a causal effect of government ideology on economic policies is to use an instrumental variable approach. Finding valid instrumental variables for government ideology remains one of the major challenges in empirical research on partisan politics. So far, experts have not found a variable that predicts government ideology, but is not correlated with the policy measure used as dependent variable (other than through the instrumented government ideology variable).

Because identifying causal effects is essential for reliable inference (and for getting papers published in top journals), many studies executed since around 2008 do not use OECD panel data to examine ideology-induced effects, but municipal data that make it possible to use RDD-designs. By using an RDD design and Swedish data, for example, PetterssonLidbom (2008) has shown that leftwing-governments spend about 2-3\% more than rightwing governments by increasing the respective additional tax revenue.

Pettersson-Lidbom (2008) pioneered RDD tests for partisan models: "Party control changes discontinuously at $50 \%$ of the vote share, which makes it possible to implement a regression-discontinuity design. The general idea of the regression-discontinuity design is to compare the outcomes for units (e.g., political jurisdictions) whose value of an underlying targeting variable (e.g., vote share) is "just below" and "just above” a fixed threshold (e.g., 
$50 \%$ of the votes) because they, on average, will have similar characteristics except for the treatment (e.g., party control). In other words, those units slightly below the threshold will provide the counterfactual outcome for those units slightly above it because the treatment status will be "as good as randomly assigned” in the neighborhood of the treatment threshold. The inference from a regression discontinuity analysis can therefore be as credible as that from a randomized experiment (e.g., Lee 2008)””' (p. 1038). ${ }^{7}$ See, for example, Lee and Lemieux (2010) on RDD.

The unresolved causality question notwithstanding: when we would like to know whether parties matter in OECD countries or - without making any causal claims and avoiding causal language - when we would like to describe whether individual economic policy measures were more expansive under leftwing or rightwing governments, we need to look at around 100 studies described in the next section.

\section{Policies}

\subsection{Macroeconomic policies}

\subsubsection{Outcomes}

Studies in the 1990s have shown evidence of rational partisan cycles in Gross Domestic Product (GDP) growth, unemployment, inflation and monetary bases in OECD countries. A prime example is the study by Alesina and Roubini (1992) who use quarterly data for 18 countries over the period 1960-1987 and estimate panel data models, including fixed country and fixed time effects. The most important explanatory variables are dummy variables describing the type of government in the first 4, 6 and 8 quarters of a newly elected government. The authors focus on changes in governments (from leftwing to rightwing and vice versa) and do not put any emphasis on the beginning of a legislative period when, for example, a leftwing government has been in office for several legislative periods. The results

\footnotetext{
${ }^{7}$ Other applications include, for example, Folke (2014) and Freier and Odendahl (2015).
} 
show that annual growth in Gross National Product (GNP) was higher and unemployment lower in the first part of a legislative period of a leftwing government than of a rightwing government (rational partisan theory). The authors describe that the results do not support the permanent influence of government ideology on GNP growth and unemployment (traditional partisan theory). Inflation has been shown to be permanently higher under leftwing governments. Due to the fact that the RPT and the PT used output in levels, but Alesina et al. (1992) used output growth as dependent variable, it is difficult to conclude that the results of Alesina et al. (1992) reject the PT. Scholars describe that both the RPT and the PT set-ups yield the same time-profile for output levels and output growth rates and are observationally equivalent (e.g., Franzese 2000, Franzese and Jusko 2006, Hibbs 2006a). In a similar vein to Alesina and Roubini (1992), the results by Alesina et al. (1997) for 18 countries over the period 1960-1993 corroborate the RPT for annual GDP growth, unemployment and inflation. When testing for permanent ideology-induced effects, the authors use a government ideology variable distinguishing between rightwing, center-rightwing, center-leftwing, and leftwing governments (measured in period t-1). The book by Alesina et al. (1997) is an important study on partisan politics.

Robustness of the pattern of partisan effects over the legislative periods is a critical issue, especially in the early literature. Scholars examined whether results depend on whether the first part of a legislative period is assumed to last 4, 6 or 8 quarters (Alesina and Roubini 1992, Alesina et al. 1997). The more recent studies mostly do not determine whether the first part of a legislative period is assumed to last 4, 6 or 8 quarters.

Two empirical studies executed in the 2000s confirm that government ideology was associated with annual GDP growth. Osterloh (2012) uses data on for 23 countries over the period 1971-2004. The dependent variables are (a) annual GDP growth and (b) five year averaged GDP growth. Government ideology is measured by the data of Beck et al. (2001) the author relates to the common party family approach when using this data - and the CMP 
(many dimensions). Government ideology as measured by Beck et al. (2001) does not turn out to be statistically significant. By contrast, using the CMP data, the results show that governments advocating a low degree of market intervention, quite small welfare states, and incentives for business, technology and infrastructure had higher GDP growth rates than governments that did not do so. Osterloh (2012) concludes that the type of government ideology measure matters.

I also use annual GDP growth as dependent variable for a sample of 21 countries over the period 1951-2006 (Potrafke 2012). I use my government ideology data (Potrafke 2009a) and the index by Bjørnskov (2008) and elaborated on patterns in line with the traditional versus rational partisan theories. The results confirm rational partisan cycles in annual GDP growth (higher annual GDP growth in the first part of the legislative period under leftwing than rightwing governments), especially in countries with two-party systems because in these systems voters seem to better punish or reward political parties for governmental performance.

Other important books on partisan politics are Garrett (1998), Clark (2003), Sakamoto (2008) and Hartmann (2015). Garrett (1998) uses data for 14 countries over the period 19661990 and many dependent variables. Political ideology is measured by a CoG variable (capturing the representation of leftwing parties in both the cabinet and the legislature). The model also includes a variable measuring labor market institutions and an interaction term of government ideology and labor market institutions. Labor market institutions are measured by an aggregated index encompassing union density, union membership, the public sector employment share and the share of public employees who are union members. The results indicate that annual GDP growth was lower and the unemployment rate higher under leftwing than rightwing governments when labor markets were deregulated. Government ideology does not seem to be related to inflation. The major shortcoming of Garrett's study is the lack of computing marginal effects. In alternative specifications, the author also includes trade 
openness and capital mobility (both interacted with political ideology and labor market institutions). The author can merely conjecture about potential ideology-induced effects.

Clark (2003) draws on Garrett's study and improves on its empirics - particularly by computing marginal effects. The dataset includes 14 countries over the period 1966-1990 and many dependent variables. The baseline model includes Garrett's (1998) CoG measure as government ideology variable, a labor market institutions indicator and an interaction term of government ideology and labor market institutions to disentangle effects of government ideology with strongly and less strongly regulated labor markets. The author computes marginal effects of the government ideology variable depending on different values of the labor market institutions variable. The marginal effects corroborate that annual GDP growth was lower and the unemployment rate higher under leftwing than rightwing governments when labor markets were deregulated. With strongly-regulated labor markets, government ideology did not turn out to be statistically significant. When using the inflation rate as the dependent variable, government ideology did not turn out to be statistically significant, the level of labor market institutions notwithstanding.

Clark (2003) is quite ambitious in interacting variables: he adds capital mobility (having triple interactions) and exchange rate regime types (having quadruple interactions), as well as central bank independence in other specifications. I experienced some difficulties in attempting to interpret the results.

Sakamoto (2008) uses data for 18 countries over the period 1961-2001 (and splits sample for the periods 1961-1981 and 1982-2001). Government ideology is measured by dummy variables for leftwing, center and rightwing governments (Armingeon et al.). The author only includes one of the three government ideology dummy variables; indicating, for example, that the effect of leftwing governments needs to be compared to center and rightwing governments (which form one reference category). I would have expected one of the dummy variables to be excluded as a reference category. The results do not show that the 
inflation rate differed under individual types of government. Over the period 1982-2001, the unemployment rate was somewhat lower under leftwing governments compared to other governments. Annual GDP growth was somewhat higher under center governments compared to leftwing and rightwing governments, and over the period 1961-1981, somewhat lower under rightwing governments compared to center and leftwing governments.

Sakamoto (2008) uses many other dependent variables (to which I will turn below) ${ }^{8}$ and also interacts government ideology with central bank independence. I found the interaction between government ideology and central bank independence especially useful when elaborating on monetary policy.

Hartmann (2015) uses a different approach to examine partisan politics: as the dependent variable he uses an indicator describing the share of policies that should be labeled "leftwing" (or favoring a large size and scope of government) on the policies that should be labeled "leftwing" and "rightwing" (or favoring a small size and scope of government). An example of a leftwing policy is being less active in privatization or increasing corporate taxation. The author considers many policy fields in eight West European countries over the period 1985-2005. Government ideology is measured by three indicators: the index by Schmidt, Woldendorp et al. and others (assuming values between 1 and 5), and the cabinet seat shares of individual parties weighted (a) with expert surveys and (b) with the CMP data. The results show that parties mattered: leftwing governments pursued more leftwing (or expansionary) policies. The author also concludes that inferences regarding ideology-induced policies do not change when using the government ideology indices by Schmidt, Woldendorp et al. and others and the cabinet seat shares of individual parties weighted with experts surveys. The effects are much less pronounced when using the CMP data, indicating that the CMP data measure somewhat different issues such as including the election-concerns of the parties.

\footnotetext{
${ }^{8}$ Table 1 includes all dependent variables in detail. I do not discuss Sakamoto’s (2008) results on expenditures, the fiscal balances and some others in the main text.
} 


\subsubsection{Monetary policies}

Partisan effects have been identified in money growth rates and nominal short- and long-term interest rates. Alesina et al. (1997) use quarterly data for 18 countries over the period 19601993. Government ideology is measured by a variable distinguishing between rightwing, center-rightwing, center-leftwing, and leftwing governments (in period t-1). The money growth rate, long-term and short-term interest rates were permanently lower under rightwing than leftwing governments.

Cusack (2001) estimates a Taylor-rule specification using the interest rate as dependent variable. The sample includes 14 countries over the period 1961-1994. He also includes a variable measuring central bank (in)dependence and a government ideology variable that does not turn out to be statistically significant.

Politicians do not, however, directly influence monetary policies such as interest rates, but are subject to institutional restrictions, most notably central bank independence. Ideologyinduced politicians can therefore manipulate interest rate policies only when central banks are not independent and subject to government directives. An attempt to deal with this issue was made by Boix (2000). The author uses short-term real interest rates as dependent variable for a panel of 19 countries over the period 1960-1993. As a main explanatory variable of interest, he includes the cabinet seat share of leftwing parties minus a central bank independence indicator (described as socialist control of government). The author also includes a variable measuring the organizational power of labor and the interaction term between the organizational power of labor variable and the socialist control of government variable. In alternative specifications the author includes the socialist control of government variable (and interactions with the organizational power of labor variable) for individual decades. I would have expected decade dummy variables and the interaction terms between decade dummy variables to be included, as well as the socialist control of government variable. The author also includes (in levels and interacted with the socialist control of government variable): the 
decline in GDP growth, the presence of restrictions on capital controls, and the exchange rate regime. I was not quite sure whether the marginal effects of the socialist control of government variable were computed correctly. In any event, the author concluded that real interest rates were lower under leftwing governments compared to rightwing governments, “except for the mid-1970s and early 1980s and then again the mid-1990s” (p. 39).

Sakamoto (2008) interacts government ideology with a central bank (in)dependence measure. The dependent variable is the difference between discount rates and Taylor-rule implied discount rates. The coefficient estimates of the government ideology and central bank (in)dependence variable and the interaction term do not turn out to be statistically significant. However, I would have liked to see marginal effects. Belke and Potrafke (2012) estimate a Taylor-rule specification, including interactions of an index of central bank independence with government ideology. The sample includes quarterly data for 23 countries over the period 1980.1-2005.4 and excluding European Monetary Union (EMU) countries. The results show that leftist governments manage to obtain somewhat lower short-term nominal interest rates than rightwing governments when central bank independence is low. By contrast, shortterm nominal interest rates are higher under leftist governments when central bank independence is high. The effect is more pronounced when exchange rates are flexible. It is conceivable that leftist governments have pushed market-oriented policies by delegating monetary policy to conservative central bankers in an attempt to deflect the blame of their traditional constituencies.

\subsubsection{Fiscal policies}

\subsubsection{Expenditure}

Government ideology has been shown to influence fiscal policies. Leftwing governments increased overall government expenditure and tax rates from the 1960s to the 1990s. There are many studies using (types of) expenditure as a dependent variable. In an early study, Blais 
et al. (1993) used data for 15 countries over the period 1960-1987. The dependent variable is total government expenditure (as a share of GDP). Government ideology is measured by the difference between the number of seats occupied by leftwing and rightwing parties in the cabinet. The authors estimate two panel data models including the ideology variable and interaction terms between the ideology variable and (a) a minority government dummy variable and (b) and variable indicating whether there was a change in government. The ideology variable has the expected positive sign and is statistically significant, indicating that leftwing governments spent more than rightwing governments. The interaction terms, however, have negative signs and are statistically significant. The authors conclude that leftwing governments only spent more than rightwing governments when they have a majority in parliament and have been in office for quite a while. We do not know, however, to what extent this conclusion is correct because the authors did not include the level of the minority government dummy and the change variable, and did not compute marginal effects. Cusack (1997) employs data for 15 countries over the period 1955-1989 and for 16 countries over the period 1961-1989. The dependent variable is the change in overall government expenditure (as a share of GDP); the most important explanatory variable to measure political ideology is his index of government's political center of gravity (CoG). The results show that leftwing governments increased spending. By contrast, the results by Bräuninger (2005) using data for 19 countries over the period 1971-1999 do not show that government ideology predicted the change of total government expenditure (as a share of GDP). Government ideology was measured by the CMP data (dimensions on government and administrative efficiency; the need for efficiency and economy in government and administration). Using data for 18 countries over the period 1961-1993, the results by Garrett and Mitchell (2001) hardly suggest that leftwing and Christian democratic governments (as measured by individual cabinet seat shares) spent more than other types of governments. If anything, total government expenditure (as a share of GDP) was somewhat lower under leftwing and 
Christian democratic governments compared to other governments. Kittel and Winner (2005) and Plümper et al. (2005) take issue with the empirical specification by Garrett and Mitchell (2001), re-estimated the model in first differences, included the lagged dependent variable, dealt with autocorrelation and heteroskedastictiy in the residuals and also arrived at the conclusion that parties did not matter. Pickering and Rockey (2011) use government outlays as a share of GDP as dependent variable. The sample includes 17 countries over the period 1960-1998. Government ideology is measured by the CMP left-right scale data, averaged over the previous ten year period and contemporaneously. The authors estimate fixed effects models and arrive at the conclusion that government outlays were higher under leftwing than rightwing governments.

Ideology-induced effects on budget composition / individual types of government expenditure have been examined a great deal. Bräuninger (2005) elaborates on the ideologyinduced effects of budget composition by using social security expenditure as a share of social security expenditure and economic affairs. Government ideology is measured by the CMP data (dimensions on government and administrative efficiency; the need for efficiency and economy in government and administration). The sample includes 19 countries over the period 1971-1999. I was wondering to what extent the results show that government ideology had an effect (the author concludes that it does). Types of government expenditure that receive special attention include military, education expenditure, and especially social (welfare) expenditure.

Social expenditure is expected to be higher under leftwing governments than rightwing governments because leftwing parties favor income redistribution towards the poor and unprivileged citizens. ${ }^{9}$ Empirical studies show that social expenditure was higher under leftwing than rightwing governments until the end of the Cold War in 1990; with partisan effects mostly disappearing after that time. Government ideology hardly influenced public

\footnotetext{
${ }^{9}$ Theoretical models such as De Donder and Hindricks (2007) predict that leftwing parties propose more social insurance than rightwing parties.
} 
health expenditure. Electoral motives appear to have overshadowed ideology in social policymaking. In many OECD countries, rightwing parties cannot do without the electoral support of the older generation.

An early study showing that social expenditure (as a share of GDP) was higher under leftwing than rightwing governments is Hicks and Swank (1992), who use data for 18 countries over the period 1960-1982. Government ideology is measured by a 4-year averaged share of an individual party leading government. The definition of being, for example, a leftwing or rightwing party is based on Castles and Mair (1984). The authors estimate a panel data model in levels, the R-squared is larger than 0.9 , and the model is likely to suffer from instationarity problems of the dependent variable. In any event, the econometric models confirmed what anecdotal evidence and descriptive statistics indicated.

Huber et al. (1993) use social security benefits and transfer payments (both as a share of GDP) as dependent variable. The samples include 17 countries over the periods 1956-1986 and 1956-1988. Government ideology is measured by the cabinet seat shares of leftwing and religious (Christian) parties. The results show that social security benefits (as a share of GDP) were higher under leftwing and Christian religious governments compared to any other types of governments. Social security transfers payments (as a share of GDP) were higher under Christian religious governments as compared to other types of governments. The results for leftwing governments depend on the specification - statistically significant with both negative and positive signs. ${ }^{10}$

Kittel and Obinger (2003) use the growth rate in social expenditure (as a share of GDP) as the dependent variable. The sample includes 21 countries over the period 1982-1997. Government ideology is measured by the cabinet seat shares of individual parties (Schmidt).

\footnotetext{
${ }^{10}$ Wolf et al. (2014) elaborate on the generosity of social policy programs and estimate a cross-sectional model for 18 OECD countries (averaged data over the periods 1980-1999 and 1990-1999). Unemployment benefits and sick pay benefits were higher under leftwing governments. The results indicate, however, that public pension generosity decreased when leftwing governments were in power. To measure private pension policies the authors use the net private pension replacement rate and a binary variable describing whether a government introduced private pensions.
} 
Government ideology does not turn out to be statistically significant; the exception being leftwing and Christian Democratic governments increasing the growth in social expenditure in the 1980s when institutional rigidity (as measured by indices on bicameralism and federalism) was low.

Tepe and Vanhuysse (2010) use data for 21 countries over the period 1980-2005. The dependent variable cutbacks considers whether social expenditure (as a share of GDP) have been reduced over individual periods such as three years and measures the duration of time until a cutback occurred. The baseline model includes 18 large cutbacks, and 29 large and smaller cutbacks. The authors estimate a Cox proportional hazard model for repeated events. Government ideology did not predict large cutbacks. Leftwing governments, however, delayed small cutbacks.

Jensen (2012a) distinguishes between types of social expenditure: unemployment protection, old-age pensions, family services and health care. Models estimated in levels (excluding fixed country and fixed time effects) indicate that expenditure on old-age pensions and family services was higher under leftwing governments compared to their rightwing counterparts. When using expenditure on health care (as a share of GDP) as the dependent variable, government ideology does not turn out to be statistically significant. ${ }^{11}$ I do not believe that these models are well specified. The author also shows the results of error correction models, which consider the changes in individual expenditure types as dependent variables. Government ideology does not turn out to be statistically significant. The sample includes 18 countries over the period 1980-2002. In another paper (Jensen 2012b), the author estimates an error correction model considering the changes in health care expenditure as the dependent variable. The sample covers the period 1980-2002 (the number of countries is not known from reading the paper, but the author informed me that this figure is 18). The cabinet seat share of rightwing parties does not turn out to be statistically significant. In a very similar

\footnotetext{
${ }^{11}$ The results show that expenditure on health care (as a share of social spending) were lower under leftwing governments compared to rightwing governments.
} 
vein, Jensen (2011a) uses data for 18 countries over the period 1980-2001. The dependent variables are the change in health care expenditure and social care expenditure. Government ideology is measured by the share of seats leftwing parties have in parliament and the share of seats held by leftwing parties in the cabinet. The results do not show that political ideology was associated with health care expenditure. The results also do not show that political ideology was associated with social care expenditure, except for government ideology over the period 1991-2001: the change in social care expenditure was lower under leftwing governments than their rightwing counterparts. I believe that the results in the first differences of social expenditure are trustworthy (in another paper Jensen 2010 also finds that political ideology did not predict the changes in health care expenditure for the very same 18 countries over the period 1980-2000). By contrast, when using social expenditure (as a share of GDP) in levels and in an attempt to examine the long-term effect of leftwing governments, the results of Jensen (2010) - for the very same 18 countries over the period 1980-2000 - show that leftwing governments had higher social expenditure than rightwing governments. Jensen’s (2010) model, however, does not include fixed country and fixed period effects.

Advocates of the dark side of globalization maintained that globalization would restrict the room to maneuver of national governments (see Schulze and Ursprung 1999, Ursprung 2008 and Potrafke 2015 for surveys of the literature on the globalization-welfare state nexus). To test this hypothesis, I use the growth rate in social expenditure (as a share of GDP) as the dependent variable and included my government ideology index, the KOF index of globalization, and the interaction term of the government ideology index and the KOF index of globalization as explanatory variables (Potrafke 2009a). The sample includes 20 countries over the period 1980-2003. The results confirm previous studies showing that the growth in social expenditure was higher under leftwing governments in the 1980s. Over the full period 1980-2003, government ideology does not turn out to be statistically significant when globalization was proceeding at an average pace. Leftwing governments, however, had 
higher social expenditure than rightwing governments when globalization was proceeding rapidly.

The research design by Kwon and Pontusson (2010) is quite similar to mine in Potrafke (2009a). However, Kwon and Pontusson (2010) use the first difference of social expenditure (as a share of GDP) as dependent variable (this should not make a difference), include the KOF globalization index in levels (I use growth rates because I also use the dependent variable in growth rates). The dataset includes 16 countries over the period 19712002. The social expenditure data stem from two different data sources, which, in turn, give rise to structural breaks in the data. When just including government ideology and globalization without the interaction term of both variables, the results show that leftwing governments had larger changes in social expenditure than rightwing governments over the period 1981-1990. When also including the interaction term between globalization and government ideology, marginal effects show that leftwing governments had larger changes in social expenditure when economic globalization was proceeding rapidly over the period 1975-1985.

Jensen and Seeberg (2015) also estimate an error-correction model using the first difference in social expenditure (as a share of GDP) as the dependent variable. The authors elaborate on policies pursued by leftwing and rightwing governments based on whether the opposition parties had polarized policies. Platforms by the political parties are measured by the CMP data on social justice and welfare state expansion. Government ideology is measured by the cabinet shares of leftwing and rightwing parties. The model includes government ideology variables, the CMP data measuring the political platforms of the government and the opposition and the interaction terms. Marginal effects show that ideologically pronounced leftwing opposition parties mitigated the policies of rightwing governments. By contrast, ideologically pronounced rightwing opposition parties did not mitigate policies of leftwing governments. 
A more sophisticated empirical strategy has been used by Herwartz and Theilen (2014a): the authors consider both potential cointegration between social expenditure and the explanatory variables and cross-country heterogeneity in their panel data study. To examine long-run effects and cointegration with variables such as GDP and the dependency ratio, social expenditure is measured in (ln) levels. To examine short-run effects, social expenditure is measured in first differences (error correction model). Government ideology is measured by an indicator assuming values between -5 (extreme leftwing positions) and 5 (extreme rightwing positions) for the leading party in government (based on Döring and Manow 2011 and Benoit and Laver 2006). The results show that the short-run dynamics of social expenditure was influenced by government ideology, especially before elections. The dataset includes 21 countries over the period 1980-2008. The ideology-induced effect was strong in the 1980s, but has faded into the background since the 1990s.

Using a similar empirical strategy Herwartz and Theilen (2014b) also examine the long-run and short-term dynamics of public health expenditure. When distinguishing between short-term and long-run dynamics, the results show that government ideology influenced changes in health care expenditure: leftwing governments seemed to spend more than rightwing governments, but only when governments have been in power for some years. The dataset includes 22 countries over the period 1970-2008. Quite similar to the authors' study on social expenditure, government ideology is based on an ideology indicator assuming values between 0 (extreme leftwing positions) and 10 (extreme rightwing positions) for the governmental party with the most seats in parliament (Döring and Manow 2011 and Benoit and Laver 2006). The explanatory variable is the difference of the individual ideology score in country $\mathrm{i}$ in year $\mathrm{t}$ from the overall sample mean of the ideology variable. For robustness tests, the authors also consider the political ideology of the coalition in government.

I have also regressed the growth rate of public health expenditure on government ideology (Potrafke 2010a). The sample includes 18 countries over the period 1971-2004. 
Government ideology as measured by my government ideology data (Potrafke 2009a) does not turn out to be statistically significant.

Why is it that the results produced by Carsten Jensen and myself do not show an ideology-induced effect on the changes (growth in) health expenditure, but the results of Herwartz and Theilen (2014b) do? An important issue seems to be the different sample sizes. Jensen and I use data for 18 countries running until the year 2004 (at latest), Herwartz and Theilen (2014b) have data for 22 countries until 2008. We also use different ideology measures, and different empirical methods. I would expect, however, the differences in the samples to be important for explaining the different results.

The growth rate in public spending on childcare (as a share of GDP) was higher under left-liberal governments. Hieda (2013) uses data for 18 countries over the period 1980-2005. Government ideology is measured by CMP Redistributive Left-Right Position and Social Liberal-Conservative Position. The authors include both ideology measures in levels and the interaction term. The marginal effects show that the growth in public spending on childcare was higher under "redistributive-left" and "social-liberal” governments compared to the other three types of governments.

Spending on Active Labour Market Policy (ALMP) was hardly associated with government ideology. Tepe and Vanhuysse (2013) use data for 20 countries over the period 1986-2005. The dependent variables are overall ALMP spending and the sub dimensions for job creation, job training and employment assistance (as a share of GDP). Government ideology is measured by an indicator considering the cabinet seat shares of leftwing parties weighted by the CMP scores (left-right-scale). The government ideology variable does not turn out to be statistically significant when spending on overall ALMP, job training and employment assistance is used as dependent variable. The results indicate that spending on job creation was lower under leftwing compared to rightwing governments. 
An important question for future research is to what extent the demographic change will influence party platforms on social policy issues. Policy platforms on social security and public health matters are likely to undergo further changes in the light of demographic change and social policy is therefore also likely to become more controversial in the future (rising official retirement ages etc).

The studies examining ideology-induced effects on social spending basically use annual data (country-years). Many of these studies have shown that ideology-induced social spending has progressively faded into the background. Schmitt (2016) maintains that using annual data (country-years) is not helpful and employs country-cabinet data. Government ideology is measured by the cabinet seat share of leftwing parties. Social expenditure (as a share of GDP) is used for 21 countries over the period 1980-2009. The results show that social expenditure (as a share of GDP) was higher under leftwing than rightwing governments.

Leftwing governments are expected to increase the size of government, and as a result, one might also expect leftwing governments to increase military expenditure, especially when higher military expenditure gives rise to more jobs in the military industry. Rightwing governments, however, endorse discipline and hierarchies that are associated with the armed forms and also advocate interventionist foreign policies. Panel data studies indicate that rightwing/hawkish governments have been more active in military spending than leftwing governments. Bove et al. (2016) use the growth rate in military expenditure (as a share of GDP) as the dependent variable. The sample includes 22 countries over the period 1988-2009. Government ideology is measured by my index (Potrafke 2009a). The results show that rightwing governments increased military expenditure (and also decreased social expenditure; especially on old age, family and incapacity- related benefits). I use data for 23 countries over the period 1970-1997 and for 20 countries over the period 1990-2006. I also use the growth rate in military expenditure (as a share of GDP) as a dependent variable and my index to 
measure government ideology, and do not find significant effects of government ideology. The samples seem to make a difference. Whitten and Williams (2011) do not believe that measuring political ideology on a left-right scale is an appropriate way of examining ideology-induced effects on military expenditure. Instead, the authors use the CMP data (leftright scale, welfare state and international / foreign policy). The sample includes 19 countries over the period 1952-1997 (unbalanced panel). The dependent variable is military expenditure (as a share of GDP) in levels. Only including the government ideology variables shows that leftwing governments and governments favoring generous welfare states and dovish foreign policies had low military expenditure. The authors also include a variable measuring conflict involvement and interact the conflict involvement variable with the government ideology variable. Marginal effects shall show that only governments favoring generous welfare states and dovish foreign policies had a (negative) effect on military expenditure when conflict involvement was low.

Education policies are a good example of how declining electoral cohesion influenced partisan politics. Leftwing governments no longer represent the working class, but rather the middle class. Leftwing governments are expected to spend more on education than rightwing governments, because leftwing governments favor the expansion of public authority in the education system, whereas rightwing governments favor private alternatives. Many studies have shown that overall spending on education was higher under leftwing governments. There is, however, a caveat: leftwing governments will not increase total education expenditure, but rather decrease it because redistribution - the leftist's ultimate goal - can be optimized in other policy areas such as social policy.

Busemeyer (2009a) distinguishes between types of education spending in 21 countries. Total education spending is available over the period 1980-2002 and types of education spending "Primary, secondary, and non-tertiary secondary (PSNTPS) education” and tertiary education spending for the period 1991-2002 (all measured as a share of GDP). Government 
ideology is measured by the share of social democratic cabinet shares. The author estimates an error-correction model and arrives at the conclusion that leftwing governments had higher total education spending in the long-run, but less total education spending in the short-run than rightwing governments. Tertiary education spending, by contrast, was higher under leftwing governments in the short-run and the long-run. Public spending on PSNTPS education was higher under leftwing governments than rightwing governments when trade openness was pronounced (and vice versa).

The model by Ansell (2008) also shows that rightwing parties are often proponents of increased spending on universities, but views partisan choices on higher education "in a trilemma between the level of enrollment, the degree of subsidization, and the overall public cost of higher education” p. 190). The author uses data for 22 countries over the period 19801997 to test his theory. The dependent variable is tertiary education expenditure (as a share of other education expenditure). Government ideology is measured by Cusack’s CoG indicator. The results show that rightwing governments had higher tertiary education expenditure when gross tertiary enrollment was low and leftwing governments had higher tertiary education expenditure when gross tertiary enrollment was high. The author estimates his model in levels, but the R-squared are nearly one and indicate spurious regression.

The private share of education spending (overall and tertiary) was higher (lower), the higher the cabinet seat share of conservative (social democratic) parties was. The share of private tertiary education was higher, the lower the cabinet seat share of Christian democratic parties was; effects are shown for a sample of 17 countries over the period 1993-2008 (Busemeyer 2015).

Jensen (2011c) uses total education expenditure (as a share of GDP) as the dependent variable. The dataset includes 18 countries over the period 1980-2000. Government ideology is measured by the cabinet share of leftwing parties and does not turn out to be statistically significant. When interacted with deindustrialization as measured by "100 minus the sum of 
manufacturing and agricultural employment as a percentage of the working-age population” (p. 419), marginal effects show that leftwing governments had higher education expenditure when deindustrialization was pronounced.

Iversen and Stephens (2008) use active labor market spending per unemployed person, public education spending (as a share of GDP), public higher education spending (as a share of GDP), and day care spending (as a share of GDP) as the dependent variable. The sample includes 18 countries in the 1990s (the exact time periods covered are not described). Government ideology is measured by two variables: a leftwing cabinet variable assuming the value one "for each year when the left is in government alone scored as a fraction of the left's seats in parliament of all governing parties’ seats for coalition governments, 1946 to date” (p. 615), and a Christian Democratic cabinet variable considering religious parties' government share and coded in the same way as the leftwing cabinet variable. The results show that active labor market spending per unemployed person, public education spending (as a share of GDP), public higher education spending (as a share of GDP), and day care spending (as a share of GDP) were all higher under leftwing governments as compared to the other types of government.

I examine whether government ideology predicted budget composition using the COFOG (Classification of the Functions of Government) classifications of government functions. The dependent variables are the individual expenditure categories (as a share of GDP) in growth rates. Leftwing governments increased spending on "Public Services" in the period 1970-1997 and on "Education” in the period 1990-2006. Castro and Martins (2016a) take a step forward and also examine the subcategories of the subcategories. They end up with 78 expenditure categories, which they use as the dependent variables (all measured in log levels). Government ideology is measured by a dummy variable for leftwing governments, which lacks statistical significance in 70 of the 78 cases. The results indicate that leftwing governments had higher expenditures for "other environmental protection”, “public health 
services”, “R\&D health”, “R\&D recreation, culture and religion”, “secondary education”, "general education expenditure not defined by level” and "survivors” and lower expenditure for “community development” than rightwing governments.

\subsubsection{Taxes}

There are only a few studies on the ideology-induced effects on tax rates and tax revenues. Two reasons spring to mind: firstly, when using tax revenues as the dependent variables, governments certainly have less means to influence tax revenues (which depend on the business cycle) than expenditure. Secondly, when using tax rates as the dependent variables, there is also a lack of comparable data across countries.

Huber et al. (1993) use total revenues (as a share of GDP) as dependent variable. The sample includes 17 countries over the period 1960-1988 and 1956-1988. The empirical strategy is described in section 4.2.3.1: government ideology is measured by the cabinet seat shares of leftwing and religious (Christian) parties. The results show that total revenues (as a share of GDP) were higher under leftwing and Christian religious governments compared to any other types of governments.

Angelopoulos et al. (2012) explicitly focus on ideology-induced tax policies in OECD countries. The sample includes 16 countries over the period 1970-2000. The dependent variables are effective tax rates on labor income, capital income and consumption. The authors use several government ideology indicators (Budge et al. 1993 and Woldendorp et al. 1998; Tavares 2004; Castles and Mair 1984 and Cusack 1997). The results show that the ratio of effective tax rates on labor income relative to capital income were lower under leftwing governments compared to rightwing governments, indicating that leftwing governments put more emphasis on capital income than labor income taxation. The authors also use the individual effective tax rates in levels as dependent variables: effective tax rates on capital income were indeed somewhat higher under leftwing governments. Government ideology 
does not turn out to be statistically significant when effective tax rates on labor income are used as the dependent variable. Effective tax rates on consumption were higher under leftwing compared to rightwing governments. Beramendi and Rueda (2007) derive similar results for average effective tax rates on average household consumption. The authors use data for 16 countries over the period 1965-1995 (five-year averages), include government ideology, corporatism and the interaction terms between government ideology and corporatism. Government ideology is measured by the cabinet seat share of social democratic parties. Corporatism is measured by an index that includes business centralization, wage setting coordination etc. Marginal effects show that average effective tax rates on average household consumption were higher under leftwing governments when corporatism was pronounced and vice versa.

Cusack and Beramendi (2006) examine ideology-induced effects on average effective tax rates on labour. The sample includes 14 countries over the period 1965-1995. Political ideology is measured by two variables: the political orientation of the cabinet and the legislature. The authors also include a variable measuring the extent to which the parliament dominates the executive (legislative institutional dominance) and the interaction term between political gravity of the legislature (not political gravity of the cabinet - I did not understand why). The authors interpret their results showing that "leftist parties, particularly in political systems where legislatures dominate the executive, push for higher taxes on labour with the apparent motive of helping to finance welfare spending” (p. 68), but do not compute any marginal effect.

In European countries (also including some non-OECD member states), tax rates such as statutory corporate income tax rates and effective tax rates were higher under leftwing governments over the period 1980-2006, but the partisan effect did indeed decline over the course of time (Osterloh and Debus 2012). The authors measure government ideology by the CMP data (left-right scale and individual policy dimensions such as preferences for the 
welfare state) and find pronounced effects. When using conventional ideology indices relating to the party families, ideology-induced hardly turn out to be statistically significant. The authors conclude that measuring government ideology does make a difference.

Sakamoto (2008) uses revenues of individual income taxes, corporate income taxes, consumption taxes, social security contributions, and total government revenues (each measured as a share of GDP) as dependent variables. The sample includes 18 countries over the period 1961-2001. Government ideology is measured by dummy variables for leftwing, center, and rightwing governments. The results show that individual income tax revenues were lower under rightwing governments and corporate income tax revenues were lower under leftwing governments compared to the other types of governments (especially over the period 1982-2001). Consumption tax revenues were lower under center governments and higher under leftwing governments. Social security contributions were lower under leftwing governments over the period 1961-1981. Total government revenues were somewhat higher under center governments over the period 1982-2001.

\subsubsection{Deficits and debt}

Empirical evidence on deficit spending is ambiguous and does not clearly indicate that leftwing governments increased public debt and budget deficits. Alesina et al. (1993) use data for 13 countries over the period 1964-1985 (unbalanced panel). The dependent variable is the change in the debt-to-GDP-ratio. Government ideology is measured by a dummy variable for leftwing governments. The results show that "left wing governments have one-half percent [of GDP] higher real fiscal deficits per year in office” (p. 18). Boix (2000) uses the annual change in the debt-to-GDP-ratio as the dependent variable for 19 countries over the period 1962-1993. Government ideology is measured by the cabinet seat share of leftwing parties. The author interacts government ideology with many variables (the decline in GDP growth, the presence of restrictions on capital controls, and the exchange rate regime), as already 
described in the section on monetary policy (the empirical analysis has shortcomings). The results indicate that policies were more expansionary under leftwing than rightwing governments in the 1970s - a conclusion that was also drawn by Volkerink and de Haan (2001) in yet another study with a somewhat different focus.

Cusack (2001) uses the budget balance as a share of GDP (net lending between general government total revenues and expenditures) as the dependent variable in a panel data model for 14 countries over the period 1961-1994. He includes his CoG government ideology variable and an interaction term between the government ideology variable and the unemployment rate. The coefficient of the government ideology variable has a positive sign (indicating that leftwing governments had balanced budgets) and the coefficient of the interaction term has a negative sign (indicating that leftwing governments had deficits when unemployment was high). Unfortunately, the author does not compute the marginal effects that would describe at which values of unemployment government ideology would have a statistically significant positive/negative effect. In a similar vein, Cusack (1999) also uses net lending (as a share of GDP) for 14 countries over the period 1961-1991 and includes many interaction terms between government ideology and the unemployment rate and decade dummy variables. The author computed marginal effects suggesting, for example, that leftwing governments had fiscal deficits when the unemployment rate was high. The results also show that when only government ideology (and other controls) is included, leftwing governments had more balanced budgets than rightwing governments. A related study was executed by Carlsen (1997) who uses data for 18 countries over the period 1980-1992. The dependent variables are the general government structural deficit and the non-adjusted government deficit (both measured as a share of GDP). The results show that leftwing governments were only associated with higher deficits when the unemployment rate was high or increasing. Alesina et al. (1997) use the change in the debt-to-GDP-ratio as the dependent variable in a sample of 13 countries over the period 1961-1993. Government ideology is 
measured by a dummy variable for leftwing governments, which does not turn out to be statistically significant.

A prominent reason proposed for why rightwing governments also increase public debt and budget deficits was that the rightwing governments' desire to reduce the scope for maneuver of their successors (Alesina and Tabellini 1990, Persson and Svensson 1989). Rightwing governments certainly often ran budget deficits (e.g., President Reagan in the United States to finance tax cuts, and Helmut Kohl after German unification to finance extraordinary spending related to unification are cases in point). Empirical studies, however, hardly corroborate that rightwing governments used debt and budget deficits to reduce the scope for maneuver of their successors (see Eslava 2011 for a survey that also includes other studies that are not based on OECD panel data).

A fairly frequently cited paper on the effect of government ideology on fiscal consolidation is Tavares (2004). The author uses data for 19 countries over the period 19601999. The paper is known for showing that government ideology does not influence budget deficits, but that leftwing governments reduce budget deficits by raising tax revenues and rightwing governments reduce budget deficits by cutting expenditure. Well-prepared descriptive statistics do indeed corroborate this take-away-message. Government ideology is measured in manifold ways by using the indicators of Budge et al. (1993) and Woldendorp et al. (1998), Warwick (1994), Laver and Hunt (1992), and Castles and Mair (1984). I am not sure, however, to what extent the econometric results indeed show what the paper gets credit for. The author estimates probit models in which the dependent variable assumes the value one when fiscal consolidation was successful. What being successful means certainly becomes quite complicated (and somewhat arbitrary): “a fiscal adjustment is defined as yearly change in the deficit of at least $-1.5 \%$ of GDP. It is considered successful if the average deficit decreases 3 years after the adjustment year or the level of public debt decreases by $5 \%$ after those 3 years. The dummy for success takes the value 0 when neither of the criteria is met” 
(footnote 35 on p. 2457). The author includes as explanatory variables the ideology variables and interaction terms of the ideology variables and variables describing changes in spending or revenues (for example the change in overall spending or the change in social security spending). Marginal effects of the estimated coefficients of the binary choice model are computed - there are, however, no marginal effects describing the effect of government ideology conditional to the interacted variables. ${ }^{12}$

\subsubsection{Financial crisis starting in 2007}

An interesting issue is whether government ideology influenced fiscal policies during the financial crisis starting in 2007. Did rightwing and leftwing governments pursue different fiscal strategies? We did not observe that leftwing governments designed especially generous rescue packages or see any failure of rightwing governments to do so. There are some empirical studies examining ideology-induced policies over the course of the financial crisis starting in 2007. Raess and Pontusson (2015) describe fiscal policy responses to economic downturns in countries since 1980-1981 and also elaborate on the recession in 2008-2009. The authors arrive at the conclusion that government ideology hardly influenced any of the fiscal stimulus packages. During the Great Recession in 2008-2009, however, leftwing governments spent more than rightwing governments in large welfare states (as measured by non-elderly social spending in 2007 - below or above $14 \%$ of GDP). ${ }^{13}$ Another study on ideology-induced borrowing is Müller et al. (2016), who regress the change in the debt-toGDP-ratio on dummy variables for leftwing and center governments (rightwing governments being the reference category). The sample includes 24 OECD countries over the period 1950-

\footnotetext{
${ }^{12}$ The paper also includes estimates in which GDP growth, private investment, business investment, housing investment, and private consumption are used as dependent variables. The explanatory variables are government ideology, change in public spending, change in public consumption and the two interaction terms between government and the change in public spending, and government ideology and the change in public consumption. I also had difficulties in interpreting these results.

${ }^{13}$ The authors' sample includes 20 OECD countries. Armingeon (2012) uses a sample of 34 "EU countries and mature non-EU democracies in 2008 and 2009” (p. 545), estimates an ordered logit model (the dependent variable assumes three values for strongly countercyclical, slightly countercyclical and pro-cyclical fiscal policies) and concludes that government ideology did not matter.
} 
2010. The results show that over the full period 1950-2010, government ideology does not turn out to be statistically significant. When excluding the years of the financial crisis and focusing on the period 1950-2007, the results indicate that leftwing governments had smaller

budget deficits than center and rightwing governments. In other words, during the financial crisis, government ideology did not help to predict budget deficits. In fact, I conjecture that new extremist parties emerged precisely because the established parties in industrialized countries did not offer finely nuanced party platforms and discussed whether rescuing is the silver bullet. The party systems have changed in many countries since the outbreak of the financial crisis. I will return to that issue in the conclusion.

\subsection{Privatization and deregulation}

Rightwing governments have been more active in privatizing state-owned companies and in deregulating product markets (Gas, Energy, and Telekom) than their leftwing counterparts. The effects are stark. Ideology-induced deregulation and privatization policies are excellent cases in point for international partisan waves in the 1970s and 1980s. Prime examples were the new governments in the United States and the United Kingdom. In 1981, the Republican Ronald Reagan became President of the United States. In 1979, Margaret Thatcher became Prime Minister of the United Kingdom. Reagan and Thatcher believed in the market economy and were active in privatization and market deregulation. There were partisan spillovers across countries, because the zeitgeist endorsed schools of thought such as liberalism or Keynesianism.

An early study examining what determines economic reforms is Pitlik (2007). The author uses the Economic Freedom of the World Index (EFW) as the dependent variable (Gwartney and Lawson 2004). The sample includes 23 countries over the period 1970-2000. The EFW is only available every fifth year $(1970,1975,1980, \ldots)$ and is measured in five broad areas: size of government (expenditure, taxes and enterprises), the legal structure and 
security of property rights, access to sound money, freedom to trade internationally, and the regulation of labor, credit and business. Pitlik's (2007) emphasis is not on government ideology. As a control variable, he includes the five-year averaged cabinet shares of leftwing parties. The model is estimated by a Generalized Method of Moments (GMM) estimator. The results show that leftwing governments were associated with less overall economic freedom than rightwing governments. Evidence on the sub-dimensions of the EFW, however, is mixed: the government ideology variable is statistically significant and negative when the size of government and regulation sub indicator is used, positive when the monetary policy and legal structure index is used, and does not turn out to be statistically significant when the trade policy index is used as the dependent variable.

One issue, however, is that national governments cannot influence all variables included in the EFW index, and particularly components included in the monetary policy and trade area. Jäger (2016) therefore excludes the components that national governments cannot directly influence (trade and monetary policies, and credit market deregulation). He also excludes the area "Legal System and Security of Property Rights”, maintaining that leftwing and rightwing governments in countries do not disagree on the protection of property rights. The overall sample includes 36 countries, including 28 OECD countries over the period 20002012. Government ideology is measured by drawing on the data of Armingeon et al. The results show that rightwing governments were more active in promoting economic freedom than their leftwing counterparts- an effect that also holds for the 28 OECD countries included.

Privatization of state-owned companies was certainly ideology-induced. Boix (1997a) used data for some countries over the period 1979-1992. Privatization is measured by the volume of public assets sold (as a share of GDP) and a self-compiled index describing "strategies towards the public business sector" assuming five values of privatization intensity. Government ideology is measured by the cabinet seat share of individual parties and an index 
considering party positions on public control of ownership. The results show that rightwing governments were more active in privatizing than leftwing governments.

Belke et al. (2007) use annual panel data for 22 countries over the period 1990-2001. The dependent variable is privatization revenues (as a share of GDP). Government ideology is measured by the share of leftwing and rightwing party seats in the cabinet. The results show that rightwing governments were more active in privatization than leftwing governments. When the sample is restricted to EU countries, however, government ideology is hardly statistically significant.

Bortolotti and Pinotti (2008) use increases in total privatization revenue (as a share of GDP) as the dependent variable. The sample includes 21 countries over the period 1977-2002. Government ideology is measured by the average of the cabinet seats weighted by the ideological orientation of the individual parties (a measure based on experts' interviews; Huber and Inglehart 1995). The effect of government ideology is strong: rightwing governments were more active in privatization. ${ }^{14}$

Obinger et al. (2014) compile new data on privatization measuring the turnover of public enterprises in relation to GDP. The sample includes 20 countries over the period 19802007. The authors estimate panel data models with governments/cabinets as units of observation. In Germany, for example, the rightwing governments under Chancellor Helmut Kohl are considered by four cabinets. Government ideology is measured by three types of cabinet seat shares (leftwing, Christian democratic and conservative) and a government ideology indicator distinguishing between leftwing and rightwing governments. The results

\footnotetext{
${ }^{14}$ Bortolotti et al. (2004) also examine whether government ideology predicted privatization in 34 developed and developing countries. Roberts and Saeed (2012) analyze the determinants of privatization in 50 countries over the period 1988-2006. Privatization is measured by the number of privatization deals and privatization revenues. Government ideology is measured by a dummy variable for rightwing governments. The results for 13 advanced countries do not show that rightwing governments were active in privatization. However, the fact that the authors use a sample for only 13 countries makes it difficult to compare the results with related studies that use data for over 20 countries.
} 
show that leftwing governments were less active in privatization than their rightwing counterparts.

Government ideology was not associated with privatizations in the health care sector. This result is in line with the studies showing no evidence for ideology-induced health care spending. Wiese (2014) compiles data on 22 de facto health care financing privatizations in 23 countries over the period 1960-2010. Government ideology is measured by my index (Potrafke 2009a).

Unemployment replacement rates have also been used as the dependent variable. Jensen (2012b) estimates an error correction model using the changes in unemployment replacement rates as the dependent variable. The sample includes 18 countries over the period 1980-2002. Government ideology is measured by the cabinet seat share of rightwing parties. The results of the baseline model show that the change in replacement rates was lower under rightwing governments compared to leftwing governments. The author also includes the unemployment rate and the KOF globalization index and the interaction terms between the government ideology variable and the unemployment rate and the KOF globalization index. Marginal effects show the changes in the replacement rates were lower under rightwing governments when unemployment and globalization were less pronounced.

A prominent paper on the effect of government ideology on welfare state reforms is Allan and Scruggs (2004). The authors use the changes in the unemployment and sick pay replacement rates as dependent variables. The sample includes 18 countries over the period 1975-1999. Government ideology is measured by the cabinet seat shares of individual parties (data by Swank). An important issue is that the authors include a dummy variable assuming the value one since the early 1980s in which individual countries experienced a recession ("break" dummy variable) and the interaction term between government ideology and the break dummy variable. The results show that leftwing governments were active in increasing 
replacement rates before the recessions in the early 1980s and rightwing governments were active in decreasing replacement rates after the recessions in the early 1980s.

Another frequently-cited paper on government ideology and welfare state reforms is Korpi and Palme (2003). The authors focus on cuts in replacement rates when individuals are sick, have work accidents and are unemployed. The paper features a wealth of descriptive statistics. Its authors also estimate econometric models. The sample includes 18 countries over the period 1976-1995. The dependent variable seems to be binary assuming the value 1 in cases where a "cut” in the replacement rates took place (19 cuts in the overall sample). The appendix includes "Definitions of Major Cuts". Government ideology seems to be measured by the number of cabinet seats held by leftwing and rightwing parties respectively. I had difficulties understanding what the authors actually do. Their results supposedly show that leftwing governments were more hesitant in cutting replacement rates than rightwing governments.

Government ideology predicted mobile telecommunications liberalization. Duso and Seldelachts (2010) use a panel for 24 countries over the period 1991-1997. Mobile telecommunications liberalization is measured by "the number of firms that are licensed to compete in the mobile telecom industry in a given country/year..., and takes on the values of one (monopoly), two (duopoly) or three (three or more firms)” (p. 204). Government ideology is measured by CMP's pro market regulation and pro welfare state limitation. The results show that governments with pro market regulation that oppose welfare state limitation were less active in liberalizing the mobile telecommunication markets. Rightwing governments as measured by the CMP's left-right dimension were also active in liberalizing the mobile telecommunication markets over the period 1993-1997 (Duso and Röller 2003).

Potrafke (2010b) examines whether government ideology influenced product market deregulation by using data on non-manufacturing regulation indicators (Conway and Nicoletti 2006). The indicators measure restrictions on competition in the seven most regulated 
industries in OECD countries (electricity, gas, air passenger transport, rail transport, road freight, postal services and telecommunications - summarized by ETCR) and assume values between 0 (minimum of regulation) and 6 (maximum of regulation). The dependent variable is the growth rates in four indices “Aggregate ETCR”, “All but public ownership”, "Entry barriers" and "Public Ownership". Government ideology is measured by the indices of Potrafke (2009a) and Bjørnskov (2008). The results show that rightwing governments were more active in deregulating product markets than leftwing governments.

Belloc and Nicita (2011) disentangle the ideology-induced effects of leftwing and rightwing governments from those of center governments. The authors focus on network industry deregulation in 30 countries over the period 1975-2006. The dependent variable is the annual change in the network industry deregulation that the authors compute based on the entry to barriers index by Conway and Nicoletti (2006). Government ideology is measured by dummy variables for leftwing and rightwing governments (in period t-1) based on the data by Beck et al. (2001), Potrafke (2009a) and Armingeon et al. The results show that both leftwing and rightwing governments promoted network industry liberalization as compared to center governments. The authors make a case of contrasting with previous results that (only) rightwing governments have been active in deregulation policies. Countries in which leftwing governments deregulated network industries include Denmark, France, Germany, Spain and the United States. In a similar vein, Belloc et al. (2014) also use dummy variables for leftwing and rightwing governments to disentangle the effects of leftwing and rightwing governments on privatization and product market deregulation in 30 countries over the period 1975-2006. Based on the updated data by Conway and Nicoletti (2006), the authors used the modified Entry Barriers Level variable to measure "Liberalization” and the modified State Ownership Level to measure "Privatization". The dependent variables are the first differences in the modified indicators. The results show that leftwing governments were more active in “Liberalization” and rightwing governments were more active in "Privatization”. 
Galasso (2014) also uses the product market deregulation and public ownership indicators by Conway and Nicoletti (2006). The sample includes 25 countries over the period 1975-2008. Government ideology is also measured by dummy variables based on the Beck et al. (2001) data: he includes a dummy variable for rightwing and center governments. As compared to Potrafke (2010b) and Belloc and Nicita (2011) and Belloc et al. (2014), he uses the level of the indicators as the dependent variable (not the first difference or growth rate). The results show that rightwing governments had laxer product market deregulation and less public ownership than leftwing governments. The center government variable does not turn out to be statistically significant. Galasso (2014) also uses financial market reform indicators by the IMF, the employment protection legislation (EPL) index by the OECD, unemployment benefit replacement rates and an indicator for retirement incentives as dependent variables. Empirical evidence is mixed. The author wishes to examine whether the effects of government ideology differ in times of crises. He defines a crisis dummy variable assuming the value one when "the output gap, defined as the difference between actual output and potential output, is below the $90^{\text {th }}$ percentile of the empirical density (which is equal $-3.4 \%$ )" (p. 154). The entire sample includes 76 years of crisis. The author interacts the government ideology dummy variables with the crisis dummy, but does not compute marginal effects. The definition of the crisis dummy is also, of course, quite arbitrary, which begs the question as to why the author did not use the continuous output gap variable. Conclusions are that rightwing governments hesitate in implementing reforms in the course of an economic crisis, but leftwing governments privatize. In fact, center governments (as compared to leftwing governments) were active in market liberalization and reducing unemployment benefits.

Chang and Berdiev (2011) use the growth rates in the indicators on gas industry and electricity industry regulation by Conway and Nicoletti (2006) as dependent variables. The sample includes 23 countries over the period 1975-2007. Government ideology is measured by my index (Potrafke 2009a) and an indicator that uses the party family coding by Beck et al. 
(2001) weighted by the seats of the governing parties in parliament. The results show that leftwing governments were more active in regulating the gas and electricity industries than rightwing governments. ${ }^{15}$

The effect of government ideology on product market deregulation may depend on the fragmentation of the legislature. Smith and Urpelainen (2016) also use the product market deregulation indicators by Conway and Nicoletti (2006) for 29 countries over the period 1978-2007. The authors use the product market deregulation indicators in levels (and include the lagged dependent variable as an explanatory variable). Government ideology is measured by dummy variables for leftwing, center, and rightwing governments (based on Beck et al. 2001 and Potrafke 2009a). Fragmentation of the legislature is measured by the "DPI measure of legislative fractionalization for political competition (Frac). This measure gives the probability that two randomly chosen deputies from the legislature represent different political parties” (p. 67). The baseline model includes a government ideology variable, the legislative fractionalization variable and the interaction term of both variables. The results show that rightwing governments were active in deregulating product markets when legislatures were strongly fractionalized. The effect is especially driven by ideology-induced deregulation in the telecommunications, rail and gas industries.

An interesting question regarding this strand of literature on partisan politics is whether using data on relatively new countries such as the Czech Republic, Hungary, Mexico, Poland, Slovakia, South Korea and Turkey gives rise to different conclusions on ideologyinduced policies.

\footnotetext{
${ }^{15}$ In EU countries, the regulation of genetically modified organisms (GMOs) was more pronounced when Christian democratic parties were in government, especially when the minister of the environment was a Christian democrat (Bäck et al. 2015).
} 


\subsection{Environment and energy}

Leftwing governments are expected to be more active in environment protection than rightwing governments. Neumayer (2003) was among the first to examine the effect of government ideology on air pollution. The dataset includes up to 21 countries over the period 1980-1999. Government ideology is measured by three variables: the share of green or leftlibertarian parties in parliament, the share of seats held by traditional leftwing parties in parliament, and the share of cabinet seats held by leftwing parties (data by Swank 2002). The dependent variables are per capita emissions of carbon dioxide, sulphur dioxide, nitrogen dioxide, carbon monoxide and volatile organic compound. The author concludes “combined left-wing party strength in government is possibly associated with higher pollution levels, but this result is also far from robust and practically small” (p. 203). In a similar vein, Garmann (2014) uses the growth rate in carbon dioxide emissions per unit GDP as the dependent variable. The sample includes 19 countries over the period 1992-2008. Government ideology is measured by the indicators of Woldendorp et al. The results show that the growth rate in carbon dioxide emissions per unit GDP was lower under leftwing than rightwing governments.

Another measure of environmental outputs is the ENVIPOLCON dataset by Holzinger et al. (2008a, 2008b) covering, for example, water and air pollution control and soil protection. Knill et al. (2010) use the ENVIPOLCON data for 18 countries for four points in time (1970, 1980, 1990 and 2000). Government ideology is measured by manifold variables based on the CMP data. The results show that governments whose parties are more inclined towards environmental protection, and especially leftwing governments, were actually more active in protecting the environment. The environmental policy positions of the environmental minister, however, did not matter. Given that the authors include many ideology variables for 
the same time, it is worth considering whether multicollinearity is an issue when the individual ideology variables are correlated with each other. ${ }^{16}$

Green parties in government in particular have been shown to try hard to fulfil the Kyoto Protocol requirements to reduce greenhouse gas emissions. Jensen and Spoon (2011) use data for 15 European OECD countries over the period 1998-2003. The dependent variable is the change in the distance to the greenhouse gas emissions target. Government ideology is measured by the CMP data (left-right scale and environment protection) and the number of seats held by Green members of parliament and a dummy variable measuring whether Greens were in government. The results show that pro-environment governments and the Greens in government reduced the distance between actual greenhouse gas emissions and the target. An intriguing result is that the higher the share of Green MPs, the larger the distance between actual greenhouse gas emissions and target levels.

Aklin and Urpelainen (2013) examine whether leftwing governments pursue cleaner energy policies than rightwing governments. The sample includes 28 countries over the period 1989-2008. The dependent variable is the growth rate in the share of renewable in electricity generation capacity (measured on a $[0,100]$ interval). Government ideology is measured by four variables: leftwing government ideology measured by positive references to environment protection and regulation based on the CMP data (rightwing governments with negative references) and two dummy variables for changes in government from a leftwing to a rightwing government (and vice versa). The results show that the share of renewables in electricity generation increased (decreased) when the government changed from rightwing to leftwing (from leftwing to rightwing). The ideology variables based on the CMP data do not turn out to be statistically significant.

Schulze (2014) examines whether government ideology was associated with ratifying international environment agreements (IEAs) in 21 countries over the period 1971-2003. The

\footnotetext{
${ }^{16}$ In EU countries, leftwing governments promoted renewable energy sources (Cadoret \& Padovano 2016).
} 
results show that governments that were inclined towards environmentalism (as measured by the CMP data) were more likely to ratify IEAs. Government ideology on a lef-right scale did not turn out to be statistically significant.

An encompassing study on ideology-induced environmental policies has been executed by Wen et al. (2016). The authors use the Environmental Performance Index (EPI), the Environmental Health Index (EHI), and the Environmental Vitality Index (EVI) as the dependent variables. The sample includes up to 31 countries over the period 2002-2012. Government ideology is measured by common party family indicator assuming values $-1,0$ and 1 , an indicator that also uses the party seat shares as weights for the party family, the CMP (left-right scale, environmental protection, and “anti-growth” economy), and a variable focusing on Christian Democratic governments. The baseline results show that leftwing governments had a better environmental performance than other types of governments notwithstanding the dependent variable and the government ideology variable. The authors' results are interesting because they show that measuring government ideology (including the CMP data) does not change the inferences regarding the ideology-induced effects. The results also show that environmental performance was good under Christian democratic governments (similar to that under leftwing governments).

The number of people affected by natural disasters was higher under leftwing than rightwing governments: Wen and Chang (2015) used data for 30 countries over the period 1975-2013. Government ideology is measured by common party family indicator assuming values $-1,0$ and 1 , an indicator that also uses the party seat shares as weights for the party family. When using the number of deaths and damages in the course of disasters as the dependent variables, however, government ideology does not turn out to be statistically significant. 


\subsection{Others}

Leftwing governments are expected to provide more foreign aid than rightwing governments. This issue is important because foreign aid policies are nowadays debated in election campaigns. There is empirical evidence supporting ideology-induced foreign aid policies. ${ }^{17}$

Tingley (2010) examines effects of government ideology on types of foreign aid (multilateral aid and bilateral aid to low income countries and middle income countries). The dataset includes 25 countries over the period 1971-2002. The author regresses the first differences in the individual type of aid (as a share of GDP) on the first differences on government ideology indicators. Government ideology is measured by CMP data (“economic field”) and the cumulative number of cabinet seats held by leftwing and rightwing parties. The results show that leftwing governments spent more foreign aid to low income countries than their rightwing counterparts.

Brech and Potrafke (2014) use data for 23 countries over the period 1960-2009. We use 53 types of foreign aid such as overall aid, bilateral and multilateral aid, and distinguish between grants and loans, and recipient characteristics such as income group and political institutions (democracy or autocracy). The aid variables are measured as a share of GDP and used in growth rates as the dependent variables. Government ideology is measured by the indices of Potrafke (2009a) and Bjørnskov (2008). The results show that leftwing governments increased bilateral grant aid, especially to the least developed countries and lower-middle income countries. These findings seem to confirm the predictions of the partisan theories because "grants are closely analogous to domestic social welfare transfer payments, and poverty and income inequality are of greatest concern for less developed recipient countries” (p. 61).

Top income shares (1\% and $9 \%)$ are shown to be lower under leftwing governments (Schinke 2014). The dataset includes 16 countries over the period 1970-2010. The author

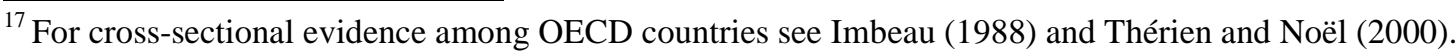


regresses the change in the top income shares on government ideology (Potrafke 2009a). In alternative specifications the author also includes the KOF globalization index and the interaction term between government ideology and the KOF globalization index. Marginal effects show that top income share were lower under leftwing government when globalization was proceeding at an average pace.

The growth rate in genuine per capita wealth was higher under rightwing governments compared to center and leftwing governments (Aidt et al. 2016). The sample includes 31 countries over the period 1981-2013. The authors also control for the number of years that rightwing governments are in office and interact the number of years that rightwing governments are in office (and its squared term) with the rightwing government dummy variable. The results suggest an inverted U-shape between the years a rightwing government is in office and the growth rate in genuine wealth. I would have liked to see a discussion of marginal effects describing whether all estimates of the inverted U-curve are statistically significant.

Gross enrolment rates in tertiary education seemed to have been higher under leftwing compared to rightwing governments. Busemeyer (2015) uses data for 21 countries and estimates an error-correction model for the period 1971-2008. Government ideology is measured by individual cabinet seat shares. The results show that the change in the gross enrolment rate in tertiary education was low (high) when the cabinet seat share of Christian Democrats (Social Democrats) was high (both long-run effects, the short-run effects do not turn out to be statistically significant). The author also presents a model using the gross enrolment rates in tertiary education in levels, but now shrinks the sample to the period 19932008 and just includes either the cabinet seat share of leftwing parties or Social Democrats or a government ideology indicator (assuming values from 1 to 5). The results show that the gross enrollment in tertiary education (level) was higher under leftwing governments (indicator) and when the cabinet seat share of Social Democrats was high (in this case 
excluding the United States and Canada). I was wondering to what extent the author was keen to show some statistically significant effects, especially because he reduces the sample to the period 1993-2008 and could, of course, have estimated the model over the period 1971-2008 for which he estimated the error-correction model.

Tax revenue forecasts were more optimistic under leftwing governments than rightwing governments indicating that leftwing governments "want to satisfy their electorate with additional expenditure plans” (Jochimsen and Lehmann 2016: 21). The sample includes 18 countries over the period 1996-2012. Government ideology is measured by the index of Manfred G. Schmidt and my index (Potrafke 2009a). The authors also interact government ideology with an election year dummy and a variable measuring government fragmentation. The results suggest that leftwing governments' optimism is especially pronounced in election years and less pronounced when governments are fragmented. I would have liked to see marginal effects corroborating this conclusion.

Government ideology has also been shown to predict types of exchange rate regimes. Berdiev et al. (2012) use the de facto exchange rates as measured by Levy-Yeyati and Sturzenegger (2005). The sample includes 154 developing and 26 developed countries. The results for developed countries show that leftwing governments were more likely to have flexible exchange rates than rightwing governments. Bodea (2015) examines whether government ideology influenced European Monetary System (EMS) realignments vis-à-vis the German currency. The sample includes nine EMS countries over the period 1979-1993. The author estimates a panel logit model using binary realignment decisions as a dependent variable. Government ideology is measured by the CMP data on statements on planned economy and market economy, and for robustness tests, by the Cabinet Center of Gravity based on expert coding (this variable assumes five categorical values from 1 to 5). The results show that the realignment risk was lower under leftwing than rightwing governments. 
Firm values as measured by Tobin's Q were higher under leftwing governments as compared to rightwing governments, a result derived for a sample of 21 countries over the period 1989-2008 (Camyar and Ulupinar 2013). Government ideology is measured by the cabinet seat shares of individual parties (Armingeon et al.). The overall sample includes some 130,000 observations (firm level data). The results show that firm values were higher under leftwing compared to rightwing governments. The authors also interact government ideology with central bank independence, trade openness and an exchange rate regime variable and compute marginal effects. Firm values were higher under leftwing compared to rightwing governments, the level of central bank independence and the type of exchange rate regime notwithstanding. By contrast, firm values were higher under rightwing compared to leftwing governments in cases where trade openness was pronounced.

Partisan approaches have also been employed in non-economic policy fields. For example, Castro and Martins (2016b) examine political cycles in the growth rate in the Human Development Index (HDI). The sample includes 34 OECD countries over the period 1980-2013. Government ideology is measured by a dummy variable for leftwing governments, but does not turn out to be statistically significant.

Government ideology has influenced political alignment with the U.S. in voting in the United Nations General Assembly (UNGA): leftwing governments were less sympathetic to US positions. The ideology-induced effect was stronger when the US President was a Republican. This finding contrasts with the declining electoral cohesion in OECD countries (Potrafke 2009b). The sample includes 21 countries over the period 1984-2005. I conclude that: "the distinctly different alignments of leftist and rightwing governments with the U.S. reflect deeper sources of ideological association than would be predicted if the issues were solely those of economic policy on a left-right spectrum” (p. 245). Leftwing governments also voted in favor of disarmament and reducing nuclear material more frequently than rightwing 
government in the UNGA. To establish this result, Filote (2016) uses data for 22 OECD countries over the period 1975-2015.

\section{Conclusions}

Leftwing and rightwing governments pursued different economic policies in OECD countries prior to the 1990s and the size and scope of government was larger when leftwing governments were in power. Partisan politics did not disappear till the 1990s, but certainly became less pronounced. More specifically, government ideology seems to still influence policies such as privatization and market deregulation.

In many OECD countries, electoral cohesion declined and the party system has changed since the beginning of the 2000s. Many would agree to not reject the "cartel-partyhypothesis" describing that political parties had formed a cartel, "employing the resources of the state to limit political competition and ensure their own electoral success” (Katz and Mair 2009: 753; see Katz and Mair 1995 and 2009 and Blyth and Katz 2005). The convergence of the policies pursued by the established leftwing and rightwing political parties enabled new populist leftwing and rightwing political parties to enter the political arena. Examples of such populist parties include the the socialist Party (Die Linke) and Alternative for Germany (AfD) in Germany. In Austria, the rightwing Freedom Party of Austria (FPÖ) has been in the national parliament since 1956, but did not become an influential political party until the beginning of the 1990s. Greece is an intriguing case for two reasons: firstly, the traditional leftwing party Panhellenic Socialist Movement (PASOK) and the traditional rightwing party New Democracy (ND) held over 80 percent of parliamentary seat up until 2012. As of September 2015, both the ND and PASOK-DIMAR have some 30.5 percent of the seats in parliament. The new dominant political party, however, is the populist leftwing SYRIZA with 48 percent of the seats. Secondly, the populist leftwing SYRIZA is a coalition partner of the 
populist rightwing party ANEL. Future research needs to capture changes in the party systems when measuring government ideology.

The OECD panel data studies on ideology-induced economic policies do not identify causal effects. The government ideology variable is not exogenous, because of reverse causality issues and potential omitted variables. I do not see any way to overcome the endogeneity problem. RDD designs do not work when using OECD macro data, because there are too few observations as yet. Exploiting natural experiments, which would give rise to exogenous variation is not suitable when using macro data for about 30 countries. There is also no instrumental variable which predicts government ideology and is certainly excludable to the economic policies to be explored. We will still need to make do with descriptive studies when elaborating on the important question of whether economic policies differ under leftwing and rightwing governments.

Issues for future research on partisan politics include examining the effects of diversity in coalition governments, time in office, political systems/institutions, and minority governments and large coalition governments, For example, to what extent do ideologyinduced economic policies depend on the beliefs of the Prime Minister compared to the Minister for Economic Affairs or the Finance Minister? ${ }^{18}$ What happens when important ministers hold different views on individual policies? When the same party (and the same Prime Minister) is in office for many years, one may expect her/him to be less enthusiastic about implementing pronounced policies and economic reforms. Do ideology-induced policies by national governments differ in federal as compared to centralist countries? Moreover, ideology-induced economic policies are certainly expected to be less pronounced when the government does not have a majority in parliament. Against the background that the number of parties in parliament (and government) has increased in many OECD countries, the

\footnotetext{
${ }^{18}$ See Bäck et al. (2016) on intra-party diversity and ministerial selection in coalition governments and Druckman and Warwick (2005) on governments’ portfolio salience.
} 
policies pursued by minority governments and coalition governments with many parties that need to gratify manifold preferences certainly merit more detailed investigation. 


\section{References}

Aidt, T., Castro, V., \& Martins, R. (2016). Shades of red and blue: Political ideology and sustainable development. NIPE Working Paper 08/2016.

Aklin, M., \& Urpelainen, J. (2013). Political competition, path dependence, and the strategy of sustainable energy transitions. American Journal of Political Science 57, 643-658.

Alesina, A. (1987). Macroeconomic policy in a two-party system as a repeated game. Quarterly Journal of Economics 102, 651-678.

Alesina, A., Cohen, G. D., \& Roubini, N. (1993). Electoral business cycles in industrial democracies. European Journal of Political Economy 9, 1-23.

Alesina, A., \& Rosenthal, H. (1995). Partisan politics, divided government, and the economy. Cambridge University Press, Cambridge.

Alesina, A., \& Rosenthal, H. (1996). A theory of divided government. Econometrica 64, 1311-1341.

Alesina, A., \& Roubini, N. (1992). Political cycles in OECD economies. Review of Economic Studies 59, 663-688.

Alesina, A., Roubini, N., \& Cohen, G. D. (1997). Political cycles and the macroeconomy. MIT press, Cambridge, MA.

Alesina, A., \& Tabellini, G. (1990). Voting on the budget deficit. American Economic Review 80, 37-49.

Allan, J. P., \& Scruggs, L. (2004). Political partisanship and welfare state reform in advanced industrial societies. American Journal of Political Science 48, 496-512.

Alt, J. E., \& Rose, S. S. (2009). Context-conditional political budget cycles. In Boix, C. \& Stokes, S. C. (Eds.), The Oxford Handbook of Comparative Politics. Oxford University Press, Oxford, New York; 845-867.

An, Y., Zhao, K., \& Zhou, R. (2016). Health spending and public pension: evidence from panel data. Applied Economics 48, 987-1004.

Angelopoulos, K., Economides, G., \& Kammas, P. (2012). Does cabinet ideology matter for the structure of tax policies? European Journal of Political Economy 28, 620-635.

Ansell, B. W. (2008). University challenges: explaining institutional change in higher education. World Politics 60, 189-230. 
Armingeon, K. (2012). The politics of fiscal responses to the crisis of 2008-2009. Governance 25, 543-565.

Armingeon, K., Isler, C., Knöpfel, L., Weisstanner, D., \& Engler, S. (2015). Comparative Political Data Set, 1960-2013. Bern: Institute of Political Science, University of Berne.

Baumann, f., \& Brändle, T. (2012). Self-employment, educational attainment, and employment protection legislation. Labour Economics 19, 846-859.

Bäck, H., Debus, M., \& Müller, W.C. (2016). Intra-party diversity and ministerial selection in coalition governments. Public Choice 166, 355-378.

Bäck, H., Debus, M., \& Tosun, J. (2015). Partisanship, ministers, and biotechnology policy. Review of Policy Research 32, 556-575.

Bawn, K., \& Rosenbluth, F. (2006). Short versus long coalitions: electoral accountability and the size of the public sector. American Journal of Political Science 50, 251-265.

Bechtel, M., \& Füss, R. (2010), Capitalizing on partisan politics? The political economy of sector-specific redistribution in Germany, Journal of Money, Credit and Banking, 42, 203235.

Beck, T.,Clarke, G., Groff, A., Keefer, P., \& Walsh, P. (2001). New tools in comparative political economy: the database of political institutions, World Bank Economic Review 15, 165-176.

Belloc, F., \& Nicita, A. (2011). The political determinants of liberalization: do ideological cleavages still matter? International Review of Economics 58, 121-145.

Belloc, F., Nicita, A., \& Sepe, S. M. (2014). Disentangling liberalization and privatization policies: Is there a political trade-off? Journal of Comparative Economics 42, 1033-1051.

Belke, A., Baumgärtner, F., Schneider, F., \& Setzer, R. (2007). The different extent of privatization proceeds in OECD countries: A preliminary explanation using a public choice approach. FinanzArchiv/Public Finance Analysis 63, 211-243.

Belke, A., \& Potrafke, N. (2012). Does government ideology matter in monetary policy? A panel data analysis for OECD countries. Journal of International Money and Finance 31, 1126-1139.

Benoit, K., \& Laver, M. (2006). Party policy in modern democracies. Routledge, New York.

Beramendi, P., \& Rueda, D. (2007). Social democracy constrained: Indirect taxation in industrialized democracies. British Journal of Political Science 37, 619-641. 
Berdiev, A.N, Y. Kim, \& Chang, C.-P. (2012). The political economy of exchange rate regimes in developed and developing countries. European Journal of Political Economy 28, 38-53.

Bjørnskov, C. (2008). Political ideology and the structure of national accounts in the Nordic Countries, 1950-2004. Paper presented at the annual meeting of the European Public Choice Society, Jena 27-30 March 2008.

Blais, A., Blake, D., \& Dion, S. (1993). Do parties make a difference? Parties and the size of government in liberal democracies. American Journal of Political Science 37, 40-62.

Blinder, A. S., \& Watson, M. W. (2016). Presidents and the US economy: An econometric exploration. American Economic Review 106, 1015-1045.

Blyth, M., \& Katz, R.S. (2005). From catch-all politics to cartelisation: The political economy of the cartel party. West European Politics 28, 33-60.

Bodea, C. (2015). Fixed exchange rates with escape clauses: The political determinants of the European Monetary System realignments. European Journal of Political Economy 39, 2540.

Boix, C. (1997a). Privatizing the public business sector in the eighties: Economic performance, partisan responses and divided governments. British Journal of Political Science 27, 473-496.

Boix, C. (1997b). Political parties and the supply side of the economy: the provision of physical and human capital in advanced economies, 1960-90. American Journal of Political Science 41, 814-845.

Boix, C. (2000). Partisan governments, the international economy, and macroeconomic policies in advanced nations, 1960-93. World Politics 53, 38-73.

Bortolotti, B., Cambini, C., \& Rondi, L. (2013). Reluctant regulation. Journal of Comparative Economics 41, 804-828.

Bortolotti, B., Fantini, M., \& Siniscalco, D. (2004). Privatisation around the world: evidence from panel data. Journal of Public Economics 88, 305-332.

Bortolotti, B., \& Pinotti, P. (2008). Delayed privatization. Public Choice 136, 331-351.

Bove, V., Efthyvoulou, G., \& Navas, A. (2016). Political cycles in public expenditure: butter vs guns. Journal of Comparative Economics, forthcoming.

Bräuninger, T. (2005). A partisan model of government expenditure. Public Choice 125, 409429. 
Brech, V., \& Potrafke, N. (2014). Donor ideology and types of foreign aid. Journal of Comparative Economics 42, 61-75.

Breitung, J. (2015). The analysis of macroeconomic panel data. In Baltagi, B. (Eds.), The Oxford Handbook of Panel Data. Oxford University Press, Oxford, New York; 453-492.

Budge, I., Keman, H., \& Woldendorp, J. (1993). Political data 1945-1990. Party government in 20 democracies. European Journal of Political Research 24, 1-119.

Budge, I., Klingemann, H.-D., Volkens, A., Bara, J., Tanenbaum, E., Fording, R. C., Hearl, D. J., Kim, H. M., McDonald, M., \& Mendez, S. (2001). Mapping policy preferences. Estimates for parties, electors, and governments 1945-1998. Oxford University Press, Oxford.

Busemeyer, M. R. (2007). Determinants of public education spending in 21 OECD democracies, 1980-2001. Journal of European Public Policy 14, 582-610.

Busemeyer, M. R. (2009a). Social democrats and the new partisan politics of public investment in education. Journal of European Public Policy 16, 107-126.

Busemeyer, M. R. (2009b). From myth to reality: Globalisation and public spending in OECD countries revisited. European Journal of Political Research 48, 455-482.

Busemeyer, M. R. (2015). Skills and inequality - partisan politics and the political economy of education reforms in Western welfare states. Cambridge University Press, Cambridge.

Cadoret, I., \& Padovano, F. (2016). The political drivers of renewable energies policies. Energy Economics 56, 261-269.

Camyar, I., \& Ulupinar, B. (2013). The partisan policy cycle and firm valuation. European Journal of Political Economy 30, 92-111.

Caynes-Wrone, B., \& Park, J.-K. (2012). Electoral business cycles in OECD countries. American Political Science Review 106, 103-122.

Carlsen, F. (1997). Counterfiscal policies and partisan politics: Evidence from industrialized countries. Applied Economics 29, 145-151.

Castles, F., \& Mair, P. (1984). Left-right political scales: some expert judgements. European Journal of Political Research 12, 73-88.

Castro, V. (2007). The causes of excessive debt in the European Union. NIPE Working Paper $13 / 2007$.

Castro, V., \& Martins, R. (2016a). Politically driven cycles in fiscal policy: In depth analysis of the functional components of government expenditures. NIPE Working Paper 02/2016. 
Castro, V., \& Martins, R. (2016b). The electoral dynamics of human development. NIPE Working Paper 06/2016.

Cazals, A., \& Mandon, P. (2015). Political budget cycles: Manipulation of leaders or bias from research? A meta-regression analysis. Études et Documents, no 3, CERDI.

Chang, C. P., \& Berdiev, A. N. (2011). The political economy of energy regulation in OECD countries. Energy Economics 33, 816-825.

Chappell, H. W.,Jr., \& Keech, W. R. (1986). Party differences in macroeconomic policies and outcomes.” American Economic Review 76, 71-74.

Cheon, A., \& Urpelainen, J. (2013). How do competing interest groups influence environmental policy? The case of renewable electricity in industrialized democracies, 1989-2007. Political Studies 61, 874-897.

Clark, W. R. (2003). Capitalism, not globalism - Capital mobility, central bank independence, and the political control of the economy. University of Michigan Press, Ann Arbor.

Conway, P., \& Nicoletti, G. (2006). Product market regulation in non-manufacturing sectors of OECD countries: measurements and highlights. OECD Economics Department Working Paper No.530, Paris.

Cusack, T. R. (1997). Partisan politics and public finance: changes in public spending in the industrialized democracies, 1955-1989. Public Choice 91, 375-395.

Cusack, T. R. (1999). Partisan politics and fiscal policy. Comparative Political Studies 32, 464-486.

Cusack, T. R. (2001). Partisanship in the setting and coordination of fiscal and monetary policies. European Journal of Political Research 40, 93-115.

Cusack, T. R., \& Beramendi, P. (2006). Taxing work. European Journal of Political Research 45, 43-73.

De Deken, J., \& Kittel, B. (2007). Social expenditure under scrutiny: the problems of using aggregate spending data for assessing welfare state dynamics. In Clasen, J. \& Siegel, N. A. (Eds.), Investigating welfare state change - The 'dependent variable problem' in comparative analysis. Edward Elgar, Celtenham, Northampton; 72-105.

De Donder, P., \& Hindriks, J. (2007). Equilibrium social insurance with policy-motivated parties. European Journal of Political Economy 23, 624-640. 
De Haan, J., \& Klomp, J. (2013). Conditional political budget cycles: a review of recent evidence. Public Choice 157, 387-410.

De Haan, J., \& Sturm, J.-E. (1994). Political and institutional determinants of fiscal policy in the European community. Public Choice 80, 157-172.

De Haan, J., \& Sturm, J.-E. (1997). Political and economic determinants of OECD budget deficits and government expenditures: A reinvestigation. European Journal of Political Economy 13, 739-750.

Downs, A. (1957). An economic theory of democracy. Harper and Row, New York.

Döring, H., \& Manow, P. (2011). ParlGov database.

Druckman, J.N., \& Warwick, P.V. (2005). The missing piece: Measuring portfolio salience in Western European parliamentary democracies. European Journal of Political Research 44, $17-44$.

Dubois, E. (2016). Political business cycles 40 years after Nordhaus. Public Choice 166, 235259.

Duso, T., \& Röller, L.-H. (2003). Endogenous deregulation: evidence from OECD countries. Economics Letters 81, 67-71.

Duso, T., \& Seldeslachts, J. (2010). The political economy of mobile telecommunications liberalization: Evidence from the OECD countries. Journal of Comparative Economics 38, 199-216.

Eslava, M. (2011). The political economy of fiscal deficits: a survey. Journal of Economic Surveys 25, 645-673.

Filote, A. (2016). Government ideology and disarmament: Evidence from voting in the UN General Assembly. Working Paper, University of Konstanz.

Folke, O. (2014). Shades of brown and green: party effects in proportional election systems. Journal of the European Economic Association 12, 1361-1395.

Franzese, R. J., JR (2000). Alberto Alesina and Nouriel Roubini with Gerald Cohen, Political Cycles and the Macroeconomy, Journal of Policy Analysis and Management 19, 501-509.

Franzese, R. J., JR., \& Jusko, K. L. (2006). Political-economic cycles. In Weingast, B. R. \& Wittman, D. A. (Eds.), The Oxford Handbook of Political Economy. Oxford University Press, Oxford, New York; 545-564. 
Freier, R., \& Odendahl, C. (2015). Do parties matter? Estimating the effect of political power in multi-party systems. European Economic Review 80, 310-328.

Frey, B. S., \& Schneider, F. G. (1978a). An empirical study of politico-economic interaction in the United States. Review of Economics and Statistics 60, 174-183.

Frey, B. S., \& Schneider, F. G. (1978b). A politico-economic model of the United Kingdom. Economic Journal 88, 243-253.

Galasso, V. (2014). The role of political partisanship during economic crises. Public Choice 158, 143-165.

Garmann, S. (2014). Do government ideology and fragmentation matter for reducing CO2emissions? Empirical evidence from OECD countries. Ecological Economics 105, 1-10.

Garrett, G. (1998). Partisan politics in the global economy. Cambridge University Press, Cambridge.

Garrett, G., \& Mitchell, D. (2001). Globalization, government spending and taxation in the OECD. European Journal of Political Research 39, 145-177.

Gaston, N., \& Rajaguru, G. (2013). International migration and the welfare state revisited. European Journal of Political Economy 29, 90-101.

Gemenis, K. (2013). What to do (and not to do) with the Comparative Manifestos Project Data. Political Studies 61, 3-23.

Gwartney, J. D., \& Lawson, R. (2004). Economic freedom of the world: 2002 annual report. Fraser Institute, Vancouver.

Hartmann, S. (2015). Partisan policy-making in Western Europe - How ideology influences the content of government policies. Wiesbaden: Springer VS.

Haussen, T., \& Uebelmesser, S. (2016). Student and graduate migration and its effects on the financing of higher education. Education Economics, forthcoming.

Hayo, B., \& Neumeier, F. (2016). Political leaders’ socioeconomic background and public deficits: evidence from OECD countries. Economics \& Politics 28, 55-78.

Helm, C., \& Neugart, M. (2013). Coalition governments and policy reform with asymmetric information. Journal of Institutional and Theoretical Economics 169, 383-406.

Herwartz, H., \& Theilen, B. (2014a). Partisan influence on social spending under market integration, fiscal pressure and institutional change. European Journal of Political Economy 34, 409-424. 
Herwartz, H., \& Theilen, B. (2014b). Health care and ideology: a reconsideration of political determinants of public health care funding in the OECD. Health Economics 23, 225-240.

Hibbs, D. A., JR. (1977). Political parties and macroeconomic policy. American Political Science Review 71, 1467-1487.

Hibbs, D. A., JR. (1992). Partisan theory after fifteen years. European Journal of Political Economy 8, 361-373.

Hibbs, D. A., JR. (1994). The partisan model of macroeconomic cycles: More theory and evidence for the United States. Economics \& Politics 6, 1-23.

Hibbs, D. A., JR. (2006a). Hibbs, D. A., JR. 1977. Political parties and macroeconomic policy. American Political Science Review 71, 1467-1487. American Political Science Review 100, 670-671.

Hibbs, D. A., JR. (2006b). Voting and the macroeconomy. In Weingast, B. R. \& Wittman, D. A. (Eds.), The Oxford Handbook of Political Economy. Oxford University Press, Oxford, New York; 565-586.

Hicks, A. M., \& Swank, D. H. (1992). Politics, institutions, and welfare spending in industrialized democracies, 1960-82. American Political Science Review 86, 658.

Hieda, T. (2013). Politics of childcare policy beyond the left-right scale: Postindustrialization, transformation of party systems and welfare state restructuring. European Journal of Political Research 52, 483-511.

Holzinger, K., Knill, C., \& Arts, B. (eds.) (2008a). Environmental policy convergence in Europe: The impact of international institutions and trade. Cambridge University Press, Cambridge.

Holzinger, K., Knill, C., \& Sommerer, T. (2008b). Environmental policy convergence: The impact of international harmonization, transnational communication and regulatory competition. International Organization 62, 553-587.

Huber, J., \& Inglehart, R. (1995). Expert interpretations of party space and party locations in 42 societies. Party Politics 1, 73-111.

Huber, E., Ragin, C., Stephens, J. D., Brady, D. \& Beckfield, J. (2004). Comparative Welfare State Data Set. Evanston, IL: Northwestern University, University of North Carolina, Duke University and Indiana University.

Huber, E., Ragin, C., \& Stephens, J. D. (1993). Social democracy, Christian democracy, constitutional structure, and the welfare state. American Journal of Sociology 99, 711-749. 
Imbeau, L. M. (1988). Aid and ideology. European Journal of Political Research 16, 3-28.

Imbeau, L. M., Pétry, F., \& Lamari, M. (2001). Left-right party ideology and government policy : a meta-analysis, European Journal of Political Research, 40, 1-29.

Iversen, T., \& Stephens, J. D. (2008). Partisan politics, the welfare state, and three worlds of human capital formation. Comparative Political Studies 41, 600-637.

Jäger, K. (2016). Economic freedom in the early $21^{\text {st }}$ century: government ideology still matters. Working paper, ifo Institute.

Jensen, C. (2010). Issue compensation and right-wing government social spending. European Journal of Political Research 49, 282-299.

Jensen, C. (2011a). Determinants of welfare service provision after the Golden Age. International Journal of Social Welfare 20, 125-134.

Jensen, C. (2011b). Marketization via compensation: health care and the politics of the right in advanced industrialized nations. British Journal of Political Science 41, 907-926.

Jensen, C. (2011c). Capitalist systems, deindustrialization, and the politics of public education. Comparative Political Studies 44, 412-435.

Jensen, C. (2012a). Two sides of the same coin? Left-wing governments and labour unions as determinants of public spending. Socio-Economic Review 10, 217-240.

Jensen, C. (2012b). Labour market- versus life course-related social policies: understanding cross-programme differences. Journal of European Public Policy 19, 275-291.

Jensen, C., \& Seeberg, H. B. (2015). The power of talk and the welfare state: Evidence from 23 countries on an asymmetric opposition-government response mechanism. SocioEconomic Review 13, 215-233.

Jensen, C. B., \& Spoon, J.-J. (2011). Testing the 'party matters' thesis: explaining progress towards the Kyoto protocol targets. Political Studies 59, 99-115.

Jochimsen, B., \& Lehmann, R. (2016). On the political economy of national tax revenue forecasts - Evidence from OECD countries. Updated Ifo Working paper No. 198.

Katz, R.S., \& Mair, P. (1995). Changing models of party organization and party democracy: The emergence of the cartel party. Party Politics 1, 5-28.

Katz, R.S., \& Mair, P. (2009). The cartel party thesis: A restatement. Perspectives on Politics 7, 753-766.

Kittel, B. (2006). A crazy methodology? On the limits of macro-quantitative social science research. International Sociology 21, 647-677. 
Kittel, B. (2008). Statistical narratives and the properties of macro-level variables: labor market institutions and employment performance in macroeconomic research. In Kenworthy, L. \& Hicks, A. (Eds.), Methods and substance in macroeconomic analysis. Palgrave, Houndmills; 29-66.

Kittel, B., \& Obinger, H. (2003). Political parties, institutions, and the dynamics of social expenditure in times of austerity. Journal of European Public Policy 10, 20-45.

Kittel, B., \& Winner, H. (2005). How reliable is pooled analysis in political economy? The globalization-welfare state nexus revisited. European Journal of Political Research 44, 269-293.

Klingemann, H.-D., Volkens, A., Bara. J., Budge, I., \& McDonald, M. (2006). Mapping policy preferences II. Estimates for parties, electors, and governments in Eastern Europe, the European Union and OECD 1990-2003. Oxford University Press, Oxford.

Knill, C., Debus, M., \& Heichel, S. (2010). Do parties matter in internationalised policy areas? The impact of political parties on environmental policy outputs in 18 OECD countries, 1970-2000. European Journal of Political Research 49, 301-336.

Korpi, W., \& Palme, J. (2003). New politics and class politics in the context of austerity and globalization: welfare state regress in 18 countries. American Political Science Review 97, 425-446.

Kwon, H. Y., \& Pontusson, J. (2010). Globalization, labour power and partisan politics revisited. Socio-Economic Review 8, 251-281.

Laver, M., \& Hunt, W.B. (1992). Policy and party competition. Routledge, Chapman and Hall, New York.

Lee, D. S. (2008). Randomized experiments from non-random selection in U.S. House elections. Journal of Econometrics 142, 675-697.

Lee, D. S., \& Lemieux, T. (2010). Regression discontinuity designs in economics. Journal of Economic Literature 48, 281-355.

Leibrecht, M., Klien, M., \& Onaran, O. (2011). Globalization, welfare regimes and social protection expenditures in Western and Eastern European countries.

Public Choice 148, 569-594.

Levy-Yeyati, E., \& Sturzenegger, F. (2005). Classifying exchange rate regimes: deeds vs. words. European Economic Review 49, 1603-1635. 
Lewis-Beck, M. S., \& Stegmaier, M. (2013). The VP-function revisited: a survey of the literature on vote and popularity functions after over 40 years. Public Choice 157, 367385.

Martin, L. W., \& Vanberg, G. (2013). Multiparty government, fiscal institutions, and public spending. Journal of Politics 75, 953-967.

Mierau, J. O., Jong-A-Pin, R. \& de Haan, J. (2007). Do political variables affect policy adjustment decisions? Public Choice 133, 297-319.

Moessinger, M.-D. (2014). Do personal characteristics of finance ministers affect the development of public debt? Public Choice 161, 183-207.

Müller, A., Storesletten, K., \& Zilibotti, F. (2016). The political color of fiscal responsibility. Journal of the European Economic Association 14, 252-302.

Neumayer, E. (2003). Are left-wing party strength and corporatism good for the environment? Evidence from panel analysis of air pollution in OECD countries. Ecological Economics 45, 203-220.

Nordhaus, W. (1975). The political business cycle. Review of Economic Studies 42, 169-190.

Obinger, H., Schmitt, C., \& Zohlnhöfer, R. (2014). Partisan politics and privatization in OECD countries. Comparative Political Studies 47, 1294-1323.

Osterloh, S. (2012). Words speak louder than actions: the impact of politics on economic performance. Journal of Comparative Economics 40, 318-336.

Osterloh, S., \& Debus, M. (2012). Partisan politics in corporate taxation. European Journal of Political Economy 28, 192-207.

Perotti, R., \& Kontopoulos, Y. (2002). Fragmented fiscal policy. Journal of Public Economics $86,191-222$

Persson, T., \& Svensson, L. E. O. (1989). Why a stubborn conservative would run a deficit: policy with time-inconsistent preferences. Quarterly Journal of Economics 104, 325345.

Pettersson-Lidbom, P. (2008). Do parties matter for economic outcomes? A regressiondicontinuity approach. Journal of the European Economic Association 6, 1037-1056.

Pickering, A. C., \& Rockey, J. (2011). Ideology and the growth of government. Review of Economics and Statistics 93, 907-919.

Pitlik, H. (2007). A race to liberalization? Diffusion of economic policy reform among OECD-economies. Public Choice 132, 159-178. 
Plümper, T., Troeger, V. \& Manow, P. (2005). Panel data analysis in comparative politics: linking method to theory. European Journal of Political Research 44, 327-354.

Plümper, T., Troeger, V. \& Winner H. (2009). Why is there no race to the bottom in capital taxation.? International Studies Quarterly 53, 761-786.

Potrafke, N. (2009a). Did globalization restrict partisan politics? An empirical evaluation of social expenditures in a panel of OECD countries. Public Choice 140, 105-124.

Potrafke, N. (2009b). Does government ideology influence political alignment with the U.S.? An empirical analysis of voting in the UN General Assembly. Review of International Organizations 4, 245-268.

Potrafke, N. (2010a). The growth of public health expenditures in OECD countries: do government ideology and electoral motives matter? Journal of Health Economics 29, 797810.

Potrafke, N. (2010b). Does government ideology influence deregulation of product markets? Empirical evidence from OECD countries. Public Choice 143, 135-155.

Potrafke, N. (2011). Does government ideology influence budget composition? Empirical evidence from OECD countries. Economics of Governance 12, 101-134.

Potrafke, N. (2012). Political cycles and economic performance in OECD countries: empirical evidence from 1951-2006. Public Choice 150, 155-179.

Potrafke, N. (2015). The evidence on globalisation. World Economy 38, 509-552.

Raess, D., \& Pontusson, J. (2015). The politics of fiscal policy during economic downturns, 1981-2010. European Journal of Political Research 54, 1-22.

Reischmann, M. (2016). Creative accounting and electoral motives: Evidence from OECD countries. Journal of Comparative Economics, forthcoming.

Roberts, B. M., \& Saeed, M. A. (2012). Privatizations around the world: Economic or political determinants. Economics \& Politics 24, 47-71.

Rogoff, K. (1990). Equilibrium political budget cycles. American Economic Review 80, $21-$ 36.

Rogoff, K., \& Sibert, A. (1988). Elections and macroeconomic policy cycles. Review of Economic Studies 55, 1-16.

Sakamoto, T. (2008). Economic policy and performance in industrial democracies - party governments, central banks and the fiscal-monetary policy mix. Routledge, London and New York. 
Schinke, C. (2014). Government ideology, globalization, and top income shares in OECD countries. Ifo Working Paper No. 181.

Schmidt, M. G. (1996). When parties matter: A review of the possibilities and limits of partisan influence on public policy. European Journal of Political Research 30, 155-186.

Schmidt, M. G. (1997). Determinants of social expenditure in liberal democracies: the post World War II experience. Acta Politica 32, 153-173.

Schmidt, M. G. (2002). The impact of political parties, constitutional structures and veto players on public policy. In Keman, H. (Ed.), Comparative democratic politics: A guide to contemporary theory and research. Sage Publications, London and others; 166-184.

Schmidt, M. G. (2003). Die parteipolitische Zusammensetzung von Regierungen in OECD Demokratien. Institute for Political Science, University of Heidelberg.

Schmitt, C. (2016). Panel data analysis and partisan variables: how periodization does influence partisan effects. Journal of European Public Policy, forthcoming.

Schulze, G.G., \& Ursprung, H.W. (1999). Globalisation of the economy and the nation state. World Economy 22, 295-352.

Schulze, K. (2014). Do parties matter for international environmental cooperation? An analysis of environmental treaty participation by advanced industrialised democracies. Environmental Politics 23, 115-139.

Smith, M.G., \& Urpelainen, J. (2013). Why has public R\&D on alternatives to fossil fuels decreased in industrialized countries? Environment Science \& Policy 25, 127-137.

Smith, M.G., \& Urpelainen, J. (2016). Windows of opportunity: legislative fragmentation conditions the effect of partisanship on product market deregulation. Journal of Public Policy 36, 51-86.

Swank, D. (2002). Political strength of political parties by ideological group in capitalist democracies. 21-nation pooled time-series data set. http://www.marquette.edu/ polisci/Swank.htm.

Tavares, J. (2004). Does right or left matter? Cabinets, credibility and fiscal adjustments. Journal of Public Economics 88, 2447-2468.

Tepe, M., \& Vanhuysse, P. (2010). Who cuts back and when? The Politics of delays in social expenditure cutbacks, 1980-2005. West European Politics 33, 1214-1240.

Tepe, M., \& Vanhuysse, P. (2013). Parties, unions and activation strategies: the contextdependent politics of active labour market policy spending. Political Studies 61, 480-504. 
Thérien, J.-P., \& Noël, A. (2000). Political parties and foreign aid. American Political Science Review 94, 151-162.

Tingley, D. (2010). Donors and domestic politics: political influences on foreign aid effort. Quarterly Review of Economics and Finance 50, 40-49.

Ursprung, H.W. (2008). Globalisation and the welfare state. in: S.N. Durlauf, \& L.E. Blume (Ed.), The New Palgrave Dictionary of Economics, Second edition. Köln: Palgrave Macmillan.

Volkens, A., Lehmann, P., Merz, N., Regel, S., Werner, A., \& Schultze, H. (2014). The Manifesto Data Collection. Manifesto Project (MRG/CMP/MARPOR). Version 2014b. Berlin: Wissenschaftszentrum Berlin für Sozialforschung (WZB).

Volkering, B., \& de Haan, J. (2001). Fragmented government effects on fiscal policy: New evidence. Public Choice 109, 221-242.

Warwick, P. (1994). Government survival in Western European parliamentary democracies. Cambridge University Press, New York.

Wen, J., \& Chang, C.-P. (2015). Government ideology and the natural disasters: a global investigation. Natural Hazards 78, 1481-1490.

Wen, J., Hao, Y., Feng, G.-F., \& Chang, C.-P. (2016). Does government ideology influence environmental performance? Evidence based on a new dataset. Economic Systems, forthcoming.

Whitten, G. D., \& Williams, L. K. (2011). Buttery guns and welfare hawks: the politics of defense spending in advanced industrial democracies. American Journal of Political Science 55, 117-134.

Wiese, R. (2014). What triggers reforms in OECD countries? Improved reform measurement and evidence from the healthcare sector. European Journal of Political Economy 34, 332352.

Woldendorp, J., Keman, H., \& Budge, I., 1998. Party government in 20 democracies: an update 1990-1995. European Journal of Political Research 33, 125-164.

Woldendorp, J., Keman, H., \& Budge, I., 2000. Party government in 48 democracies 19451998: composition, duration, personnel. Kluwer Academic Publishers, Dordrecht.

Wolf, F., Zohlnhöfer, R., \& Wenzelburger, G. (2014). The politics of public and private pension generosity in advanced democracies. Social Policy \& Administration 48, 86-106. 
Yang, W., Fidrmuc, R., \& Ghosh, S. (2015). Macroeconomic effects of fiscal adjustments: A tale of two approaches. Journal of International Money and Finance 57, 31-60. 
Table 1: Effects of government ideology. OECD panel data studies.

"+” positive effect; "-“" negative effect; "0" no significant effect; “+/0" positive effect in some specifications, no significant effect in other specifications; "-/0" negative effect in some specifications, no significant effect in other specifications; "?" authors describe to have included government ideology but do not describe the effect.

\begin{tabular}{|c|c|c|c|c|c|c|}
\hline Study & Influence on & Effect (leftwing) & Time period & \# countries & Ideology measure & $\begin{array}{l}\text { Ideology } \\
\text { main expl var }\end{array}$ \\
\hline \multicolumn{7}{|l|}{ Outcomes } \\
\hline Busemeyer (2015) & Youth unemployment & 0 & $1997-2008$ & 19 & $\begin{array}{l}\text { Ideology index; Schmidt and } \\
\text { Armingeon et al. }\end{array}$ & no \\
\hline Yang et al. (2015) & Annual GDP growth & 0 & $1970-2009$ & 20 & Potrafke (2009a) & no \\
\hline Osterloh (2012) & Annual GDP growth & $-/ 0$ & $1971-2004$ & 23 & $\begin{array}{l}\text { CMP (left-right, many } \\
\text { subdimensions), } \\
\text { Beck et al. (2001) }\end{array}$ & yes \\
\hline Osterloh (2012) & GDP growth (5 year av) & $-/ 0$ & 1971-2004 & 23 & $\begin{array}{l}\text { CMP (left-right, many } \\
\text { subdimensions), } \\
\text { Beck et al. (2001) }\end{array}$ & yes \\
\hline Potrafke (2012) & Annual GDP growth & $0 /+$ & 1951-2006 & 21 & $\begin{array}{l}\text { Potrafke (2009a), } \\
\text { Bjørnskov (2008) }\end{array}$ & yes \\
\hline Sakamoto (2008) & Annual GDP growth & $\begin{array}{c}\text { 0; + (center, 1961-2001, } \\
\text { 1961-1981); - (1961-1981) }\end{array}$ & 1961-2001 & 18 & $\begin{array}{l}\text { Cabinet seat shares of rightwing, } \\
\text { center and leftwing parties, } \\
\text { Armingeon et al. }\end{array}$ & yes \\
\hline Sakamoto (2008) & Unemployment rate & $\begin{array}{c}0 \\
(1982-2001)\end{array}$ & $1961-2001$ & 18 & $\begin{array}{l}\text { Cabinet seat shares of rightwing, } \\
\text { center and leftwing parties, } \\
\text { Armingeon et al. }\end{array}$ & yes \\
\hline Sakamoto (2008) & Inflation rate & 0 & $1961-2001$ & 18 & $\begin{array}{l}\text { Cabinet seat shares of rightwing, } \\
\text { center and leftwing parties, } \\
\text { Armingeon et al. }\end{array}$ & yes \\
\hline Sakamoto (2008) & Discount rate & $-/ 0$ & $1961-2001$ & 18 & $\begin{array}{l}\text { Cabinet seat shares of rightwing, } \\
\text { center and leftwing parties, } \\
\text { Armingeon et al. }\end{array}$ & yes \\
\hline Clark (2003) & Annual GDP growth & $\begin{array}{l}\text { - (cond on labor market } \\
\text { institutions) }\end{array}$ & $1966-1990$ & 14 & Garrett’s (1998) CoG & yes \\
\hline Clark (2003) & Unemployment rate & $\begin{array}{c}+ \text { (cond on labor market } \\
\text { institutions) }\end{array}$ & $1966-1990$ & 14 & Garrett’s (1998) CoG & yes \\
\hline Clark (2003) & Inflation rate & 0 & $1966-1990$ & 14 & Garrett’s (1998) CoG & yes \\
\hline Cusack (2001) & Nominal interest rate & 0 & 1961-1991 & 14 & Cusack’s CoG & yes \\
\hline Boix (2000) & Short-term real interest rate & $+/ 0$ & $1960-1993$ & 19 & $\begin{array}{l}\text { Cabinet seat shares of leftwing } \\
\text { parties minus central bank } \\
\text { independence }\end{array}$ & yes \\
\hline
\end{tabular}




\begin{tabular}{|c|c|c|c|c|c|c|}
\hline Study & Influence on & Effect (leftwing) & Time period & \# countries & Ideology measure & $\begin{array}{c}\text { Ideology } \\
\text { main expl var }\end{array}$ \\
\hline Garrett (1998) & Annual GDP growth & $\begin{array}{l}\text { - (cond on labor market } \\
\text { institutions) }\end{array}$ & $1966-1990$ & 14 & $\begin{array}{l}\text { CoG (aggregated index based on } \\
\text { seat share of leftwing parties in } \\
\text { cabinet and parliament) }\end{array}$ & yes \\
\hline Garrett (1998) & Unemployment rate & $\begin{array}{c}+ \text { (cond on labor market } \\
\text { institutions) }\end{array}$ & 1966-1990 & 14 & $\begin{array}{l}\text { CoG (aggregated index based on } \\
\text { seat share of leftwing parties in } \\
\text { cabinet and parliament) }\end{array}$ & yes \\
\hline Garrett (1998) & Inflation rate & 0 & $1966-1990$ & 14 & $\begin{array}{l}\text { CoG (aggregated index based on } \\
\text { seat share of leftwing parties in } \\
\text { cabinet and parliament) }\end{array}$ & yes \\
\hline Alesina et al. (1997) & Annual GNP growth & $+(\mathrm{RPT})$ & $1960-1993$ & 18 & $\begin{array}{l}\text { Dummies for changes in } \\
\text { government and } \\
\text { leftwing/rightwing governments }\end{array}$ & yes \\
\hline Alesina et al. (1997) & Unemployment rate & - (RPT) & $1960-1993$ & 18 & $\begin{array}{l}\text { Dummies for changes in } \\
\text { government and } \\
\text { leftwing/rightwing governments }\end{array}$ & yes \\
\hline Alesina et al. (1997) & Inflation rate & - (RPT) & $1960-1993$ & 18 & $\begin{array}{l}\text { Dummies for changes in } \\
\text { government and } \\
\text { leftwing/rightwing governments }\end{array}$ & yes \\
\hline Alesina et al. (1997) & Money supply growth rate & + & $1960-1993$ & 18 & $\begin{array}{l}\text { Government ideology index (four } \\
\text { types of governments) }\end{array}$ & yes \\
\hline Alesina et al. (1997) & $\begin{array}{l}\text { Nominal short term interest } \\
\text { rate }\end{array}$ & + & $1960-1993$ & 18 & $\begin{array}{l}\text { Government ideology index (four } \\
\text { types of governments) }\end{array}$ & yes \\
\hline Alesina et al. (1997) & Nominal long term interest rate & + & $1960-1993$ & 18 & $\begin{array}{l}\text { Government ideology index (four } \\
\text { types of governments) }\end{array}$ & yes \\
\hline Alesina and Roubini (1992) & Annual GNP growth & $+(\mathrm{RPT})$ & $1960-1987$ & 18 & $\begin{array}{l}\text { Dummies for changes in } \\
\text { government and } \\
\text { leftwing/rightwing governments }\end{array}$ & yes \\
\hline Alesina and Roubini (1992) & Unemployment rate & - (RPT) & 1960-1987 & 18 & $\begin{array}{l}\text { Dummies for changes in } \\
\text { government and } \\
\text { leftwing/rightwing governments }\end{array}$ & yes \\
\hline Alesina and Roubini (1992) & Inflation rate & + & $1960-1987$ & 18 & $\begin{array}{l}\text { Dummies for changes in } \\
\text { government and } \\
\text { leftwing/rightwing governments }\end{array}$ & yes \\
\hline \multicolumn{7}{|l|}{ Expenditure } \\
\hline An et al. (2016) & $\begin{array}{l}\text { Total health care (public and } \\
\text { private, per capita, log levels) }\end{array}$ & 0 & $1980-2005$ & 21 & Potrafke (2009a) & no \\
\hline
\end{tabular}




\begin{tabular}{|c|c|c|c|c|c|c|}
\hline Study & Influence on & Effect (leftwing) & Time period & \# countries & Ideology measure & $\begin{array}{c}\text { Ideology } \\
\text { main expl var }\end{array}$ \\
\hline Bove et al. (2016) & $\begin{array}{l}\text { Military (\% of GDP, growth } \\
\text { rates) }\end{array}$ & $-/ 0$ & 1988-2009 & 22 & Potrafke (2009a) & yes \\
\hline Bove et al. (2016) & $\begin{array}{l}\text { Total social (\% of GDP, } \\
\text { growth rates) }\end{array}$ & $\begin{array}{l}+/ 0(1981-2009) \\
0(1988-2009)\end{array}$ & $1981-2009$ & 22 & Potrafke (2009a) & yes \\
\hline Bove et al. (2016) & $\begin{array}{l}\text { Old age, family and incapacity- } \\
\text { related benefits (\% of GDP, } \\
\text { growth rates) }\end{array}$ & $\begin{array}{l}+(1981-2009) \\
+(1988-2009)\end{array}$ & 1981-2009 & 22 & Potrafke (2009a) & yes \\
\hline Bove et al. (2016) & $\begin{array}{l}\text { Military-to-social-ratio (\% of } \\
\text { GDP, growth rates) }\end{array}$ & $-/ 0$ & 1988-2009 & 22 & Potrafke (2009a) & yes \\
\hline Castro and Martins (2016a) & $\begin{array}{l}78 \text { individual types of exp. (all } \\
\text { measured in log levels), } \\
\text { COFOG }\end{array}$ & $\begin{array}{c}0 \text { in } 70 \text { cases } \\
+ \text { (other environment) } \\
\text { - (Community development) } \\
+ \text { (public health services) } \\
+ \text { (health R\&D) } \\
+ \text { (R\&D recreation, culture } \\
\text { and religion) } \\
+ \text { (secondary education) } \\
+ \text { (general education exp not } \\
\text { defined by level) } \\
+ \text { (survivor) }\end{array}$ & $1990-2012$ & $18(\mathrm{EU})$ & $\begin{array}{l}\text { Dummy variable for leftwing } \\
\text { governments, Beck et al. (2001) }\end{array}$ & yes \\
\hline $\begin{array}{l}\text { Haussen and Uebelmesser } \\
\text { (2016) }\end{array}$ & $\begin{array}{l}\text { Private funding share of higher } \\
\text { education }\end{array}$ & $0 /+$ & $2000-2011$ & 22 & $\begin{array}{l}\text { Share of rightwing parties in } \\
\text { parliament, weighted by the } \\
\text { number of days the government } \\
\text { was in office Armingeon et al. }\end{array}$ & no \\
\hline Schmitt (2016) & $\begin{array}{l}\text { Social (\% of GDP, cabinet- } \\
\text { country) }\end{array}$ & $+/ 0$ & $1980-2009$ & 21 & $\begin{array}{c}\text { Cabinet seat share of leftwing } \\
\text { parties }\end{array}$ & yes \\
\hline Busemeyer (2015) & $\begin{array}{l}\text { Private share of education } \\
\text { spending (level) }\end{array}$ & $\begin{array}{c}+ \text { (conservative) } \\
\text { - (social democrats) }\end{array}$ & $1993-2008$ & 17 & $\begin{array}{l}\text { Cabinet seat share of individual } \\
\text { parties; Armingeon et al. }\end{array}$ & yes \\
\hline Busemeyer (2015) & $\begin{array}{l}\text { Private share of tertiary } \\
\text { education spending (level) }\end{array}$ & $\begin{array}{c}\text { + (conservative) } \\
\text { - (social democrats) } \\
\text { - (Christian democrats }\end{array}$ & $1993-2008$ & 17 & $\begin{array}{l}\text { Cabinet seat share of individual } \\
\text { parties; Armingeon et al. }\end{array}$ & yes \\
\hline Jensen and Seeberg (2015) & $\begin{array}{l}\text { First difference in social } \\
\text { expenditure (\% of GDP) }\end{array}$ & $+/ 0$ & $1980-2007$ & 23 & $\begin{array}{l}\text { CMP (social justice, welfare state } \\
\text { expansion), Armingeon et al. }\end{array}$ & yes \\
\hline Herwartz and Theilen (2014a) & Social (changes) & + & $1980-2008$ & 21 & $\begin{array}{l}\text { Döring and Manow (2011), } \\
\text { Benoit and Laver (2006) }\end{array}$ & yes \\
\hline
\end{tabular}




\begin{tabular}{|c|c|c|c|c|c|c|}
\hline Study & Influence on & Effect (leftwing) & Time period & \# countries & Ideology measure & $\begin{array}{l}\text { Ideology } \\
\text { main expl var }\end{array}$ \\
\hline Herwartz and Theilen (2014b) & Health (changes) & + & $1970-2008$ & 22 & $\begin{array}{l}\text { Döring and Manow (2011), } \\
\text { Benoit and Laver (2006) }\end{array}$ & yes \\
\hline Gaston and Rajaguru (2013) & $\begin{array}{l}\text { Social (\% of GDP, growth } \\
\text { rates) }\end{array}$ & 0 & 1980-2008 & 25 & Beck et al. (2001) & no \\
\hline Hieda (2013) & $\begin{array}{l}\text { Child care (\% of GDP, growth } \\
\text { rates) }\end{array}$ & + & $1980-2005$ & 18 & $\begin{array}{l}\text { CMP (liberal-conservative, left- } \\
\text { right) weighted by seats in the } \\
\text { lower house }\end{array}$ & yes \\
\hline Martin and Vanberg (2013) & Overall (\% of GDP, levels) & $+/ 0$ & 1971-2009 & 15 (EU) & $\begin{array}{c}\text { CMP weighted with cabinet seat } \\
\text { shares }\end{array}$ & no \\
\hline Smith and Urpelainen (2013) & $\begin{array}{l}\text { Public energy R\&D (per capita, } \\
\text { changes) }\end{array}$ & 0 & $1980-2007$ & 20 & $\begin{array}{c}\text { Dummy variables based on Beck } \\
\text { et al. (2001) }\end{array}$ & no \\
\hline Tepe and Vanhuysse (2013) & $\begin{array}{l}\text { ALMP (\% of GDP, five year } \\
\text { averages) }\end{array}$ & 0 & 1986-2005 & 20 & $\begin{array}{l}\text { Indicator based on cabinet seats } \\
\text { of leftwing weighted by CMP }\end{array}$ & yes \\
\hline Tepe and Vanhuysse (2013) & $\begin{array}{l}\text { Job creation (\% of GDP, five } \\
\text { year averages) }\end{array}$ & - & 1986-2005 & 20 & $\begin{array}{l}\text { Indicator based on cabinet seats } \\
\text { of leftwing weighted by CMP }\end{array}$ & yes \\
\hline Tepe and Vanhuysse (2013) & $\begin{array}{l}\text { Job training (\% of GDP, five } \\
\text { year averages) }\end{array}$ & 0 & $1986-2005$ & 20 & $\begin{array}{l}\text { Indicator based on cabinet seats } \\
\text { of leftwing weighted by CMP }\end{array}$ & yes \\
\hline Tepe and Vanhuysse (2013) & $\begin{array}{l}\text { Employment assistance (\% of } \\
\text { GDP, five year averages) }\end{array}$ & 0 & $1986-2005$ & 20 & $\begin{array}{l}\text { Indicator based on cabinet seats } \\
\text { of leftwing weighted by CMP }\end{array}$ & yes \\
\hline Jensen (2012a) & $\begin{array}{l}\text { Unemployment protection } \\
\text { (levels) }\end{array}$ & 0 & $1980-2002$ & 18 & Swank & yes \\
\hline Jensen (2012a) & Old age pensions (levels) & + & $1980-2002$ & 18 & Swank & yes \\
\hline Jensen (2012a) & Family services (levels) & + & $1980-2002$ & 18 & Swank & yes \\
\hline Jensen (2012a) & Health care (levels) & $0 /-$ & $1980-2002$ & 18 & Swank & yes \\
\hline Jensen (2012a) & $\begin{array}{l}\text { Unemployment protection } \\
\text { (changes) }\end{array}$ & 0 & $1980-2002$ & 18 & Swank & yes \\
\hline Jensen (2012a) & Old age pensions (changes) & 0 & $1980-2002$ & 18 & Swank & yes \\
\hline Jensen (2012a) & Family services (changes) & 0 & $1980-2002$ & 18 & Swank & yes \\
\hline Jensen (2012a) & Health care (changes) & 0 & $1980-2002$ & 18 & Swank & yes \\
\hline Jensen (2012b) & $\begin{array}{l}\text { Health care (\% of GDP, } \\
\text { changes) }\end{array}$ & 0 & $1980-2002$ & 18 & $\begin{array}{c}\text { Cabinet shares of rightwing } \\
\text { parties; Swank }\end{array}$ & yes \\
\hline Jensen (2011a) & Social care (changes) & $0 /-$ & $1980-2001$ & 18 & Swank & yes \\
\hline Jensen (2011a) & Health care (changes) & 0 & $1980-2001$ & 18 & Swank & yes \\
\hline Potrafke (2011) & $\begin{array}{l}11 \text { individual types (\% of GDP, } \\
\text { growth rates), COFOG }\end{array}$ & $\begin{array}{c}0 \text { in } 10 \text { cases } \\
+(\text { public services })\end{array}$ & $1970-1997$ & 23 & Potrafke (2009a) & yes \\
\hline Potrafke (2011) & $\begin{array}{l}11 \text { individual types (\% of GDP, } \\
\text { growth rates), COFOG }\end{array}$ & $\begin{array}{l}0 \text { in } 10 \text { cases } \\
+ \text { (education) }\end{array}$ & 1990-2006 & 20 & Potrafke (2009a) & yes \\
\hline
\end{tabular}




\begin{tabular}{|c|c|c|c|c|c|c|}
\hline Study & Influence on & Effect (leftwing) & Time period & \# countries & Ideology measure & $\begin{array}{l}\text { Ideology } \\
\text { main expl var }\end{array}$ \\
\hline Jensen (2011b) & Health care (changes) & 0 & $1980-2000$ & 18 & Swank & yes \\
\hline Jensen (2010) & Social (levels) & + & $1980-2000$ & 18 & Huber et al. (2004) & yes \\
\hline Jensen (2011c) & $\begin{array}{l}\text { Total education (\% of GDP, } \\
\text { levels) }\end{array}$ & $\begin{array}{c}0 \\
+ \text { (conditional on } \\
\text { deindustrialization) }\end{array}$ & $1980-2000$ & 18 & $\begin{array}{l}\text { Share of leftwing government } \\
\text { seats, Huber et al. (2004) }\end{array}$ & yes \\
\hline Leibrecht et al. (2011) & Social expenditure & 0 & $1990-2006$ & 27 (Europe) & Armingeon et al. & no \\
\hline Kwon and Pontusson (2010) & Social (changes) & + & 1971-1985 & 16 & Cusack’s COG & yes \\
\hline Kwon and Pontusson (2010) & Social (changes) & 0 & $1990-2002$ & 16 & Cusack’s COG & yes \\
\hline Potrafke (2010a) & $\begin{array}{l}\text { Public health care (growth } \\
\text { rates) }\end{array}$ & 0 & $1971-2004$ & 18 & Potrafke & yes \\
\hline Tepe and Vanhuysse (2010) & $\begin{array}{l}\text { Large cutbacks of social } \\
\text { expenditure }\end{array}$ & 0 & $1980-2005$ & 21 & Armingeon et al. & yes \\
\hline Tepe and Vanhuysse (2010) & $\begin{array}{l}\text { Small cutbacks of social } \\
\text { expenditure }\end{array}$ & - & $1980-2005$ & 21 & Armingeon et al. & yes \\
\hline Busemeyer (2009a) & $\begin{array}{l}\text { Total education (\% of GDP, } \\
\text { change) }\end{array}$ & $\begin{array}{l}+ \text { (long-term) } \\
\text { - (short-term) }\end{array}$ & $1980-2002$ & 21 & $\begin{array}{c}\text { Cabinet seat share of individual } \\
\text { parties; Schmidt }\end{array}$ & yes \\
\hline Busemeyer (2009a) & $\begin{array}{l}\text { Primary and secondary } \\
\text { education (\% of GDP, change) }\end{array}$ & $\begin{array}{c}+/- \text { (long-term) } \\
0 \text { (short-term) } \\
+ \text { (conditional on trade) }\end{array}$ & 1991-2002 & 21 & $\begin{array}{l}\text { Cabinet seat share of individual } \\
\text { parties; Schmidt }\end{array}$ & yes \\
\hline Busemeyer (2009a) & $\begin{array}{l}\text { Tertiary education (\% of GDP, } \\
\text { change) }\end{array}$ & $\begin{array}{l}+ \text { (long-term }) \\
+(\text { short-term })\end{array}$ & 1991-2002 & 21 & $\begin{array}{l}\text { Cabinet seat share of individual } \\
\text { parties; Schmidt }\end{array}$ & yes \\
\hline Busemeyer (2009b) & Total (\% of GDP, change) & 0 & $1980-2004$ & 21 & $\begin{array}{l}\text { Cabinet seat share of social } \\
\text { democratic parties; Schmidt }\end{array}$ & no \\
\hline Busemeyer (2009b) & Social (\% of GDP, change) & 0 & $1980-2004$ & 21 & $\begin{array}{l}\text { Cabinet seat share of social } \\
\text { democratic parties; Schmidt }\end{array}$ & no \\
\hline Busemeyer (2009b) & $\begin{array}{l}\text { Total minus social (\% of GDP, } \\
\text { change) }\end{array}$ & $\begin{array}{l}+(\text { long-term }) \\
+(\text { short-term })\end{array}$ & 1991-2002 & 21 & $\begin{array}{l}\text { Cabinet seat share of individual } \\
\text { parties; Schmidt }\end{array}$ & no \\
\hline Potrafke (2009a) & Social (\% of GDP, growth rate) & $+/ 0$ & $1980-2003$ & 21 & Potrafke (2009a) & yes \\
\hline Ansell (2008) & $\begin{array}{l}\text { Tertiary education (\% of other } \\
\text { education expenditure) }\end{array}$ & - (when enrolment is low & 1980-1997 & 22 & Cusack’s CoG & yes \\
\hline Iversen and Stephens (2008) & $\begin{array}{l}\text { Active labor market policy (per } \\
\text { unemployed, levels) }\end{array}$ & + & $\begin{array}{l}\text { 1990s, otherwise } \\
\text { not known }\end{array}$ & 18 & $\begin{array}{l}\text { Dummy for leftwing or Christian } \\
\text { Democratic cabinet; Huber et al. } \\
\text { (2004) }\end{array}$ & yes \\
\hline Iversen and Stephens (2008) & $\begin{array}{l}\text { Total education (\% of GDP, } \\
\text { levels) }\end{array}$ & + & $\begin{array}{l}\text { 1990s, otherwise } \\
\text { not known }\end{array}$ & 18 & $\begin{array}{l}\text { Dummy for leftwing or Christian } \\
\text { Democratic cabinet; Huber et al. } \\
\text { (2004) }\end{array}$ & yes \\
\hline
\end{tabular}




\begin{tabular}{|c|c|c|c|c|c|c|}
\hline Study & Influence on & Effect (leftwing) & Time period & \# countries & Ideology measure & $\begin{array}{l}\text { Ideology } \\
\text { main expl var }\end{array}$ \\
\hline Iversen and Stephens (2008) & $\begin{array}{l}\text { Tertiary education (\% of GDP, } \\
\text { levels) }\end{array}$ & + & $\begin{array}{l}\text { 1990s, otherwise } \\
\text { not known }\end{array}$ & 18 & $\begin{array}{l}\text { Dummy for leftwing or Christian } \\
\text { Democratic cabinet; Huber et al. } \\
\text { (2004) }\end{array}$ & yes \\
\hline Iversen and Stephens (2008) & Day care (\% of GDP, levels) & + & $\begin{array}{l}\text { 1990s, otherwise } \\
\text { not known }\end{array}$ & 18 & $\begin{array}{l}\text { Dummy for leftwing or Christian } \\
\text { Democratic cabinet; Huber et al. } \\
\text { (2004) }\end{array}$ & yes \\
\hline Sakamoto (2008) & $\begin{array}{l}\text { Government wage } \\
\text { consumption (\% of GDP, } \\
\text { levels) }\end{array}$ & 0 (left), - (center) & $1961-2001$ & 18 & $\begin{array}{l}\text { Cabinet seat shares of rightwing, } \\
\text { center and leftwing parties, } \\
\text { Armingeon et al. (2002) }\end{array}$ & yes \\
\hline Sakamoto (2008) & $\begin{array}{l}\text { Government non-wage } \\
\text { consumption (\% of GDP, } \\
\text { levels) }\end{array}$ & 0 & $1961-2001$ & 18 & $\begin{array}{l}\text { Cabinet seat shares of rightwing, } \\
\text { center and leftwing parties, } \\
\text { Armingeon et al. (2002) }\end{array}$ & yes \\
\hline Sakamoto (2008) & $\begin{array}{l}\text { Government fixed (\% of GDP, } \\
\text { levels) }\end{array}$ & 0 & $1961-2001$ & 18 & $\begin{array}{l}\text { Cabinet seat shares of rightwing, } \\
\text { center and leftwing parties, } \\
\text { Armingeon et al. (2002) }\end{array}$ & yes \\
\hline Sakamoto (2008) & Subsidies (\% of GDP, levels) & $-/ 0$ & $1961-2001$ & 18 & $\begin{array}{l}\text { Cabinet seat shares of rightwing, } \\
\text { center and leftwing parties, } \\
\text { Armingeon et al. (2002) }\end{array}$ & yes \\
\hline Sakamoto (2008) & $\begin{array}{l}\text { Social security transfers (\% of } \\
\text { GDP, levels) }\end{array}$ & 0 & $1961-2001$ & 18 & $\begin{array}{l}\text { Cabinet seat shares of rightwing, } \\
\text { center and leftwing parties, } \\
\text { Armingeon et al. (2002) }\end{array}$ & yes \\
\hline Sakamoto (2008) & $\begin{array}{l}\text { Total spending (\% of GDP, } \\
\text { levels) }\end{array}$ & $\begin{array}{c}\text { - (center), + (right) 1982- } \\
2001\end{array}$ & $1961-2001$ & 18 & $\begin{array}{l}\text { Cabinet seat shares of rightwing, } \\
\text { center and leftwing parties, } \\
\text { Armingeon et al. (2002) }\end{array}$ & yes \\
\hline Busemeyer (2007) & $\begin{array}{l}\text { Total education (\% of GDP, } \\
\text { change) }\end{array}$ & - (in the 1908s)/0 & $1980-2001$ & 21 & $\begin{array}{l}\text { Cabinet seat share of individual } \\
\text { parties; Schmidt (2003) }\end{array}$ & no \\
\hline De Deken and Kittel (2007) & Social (\% of GDP, change) & - (with rigid institutions); 0 & 1993-2001 & 18 & $\begin{array}{c}\text { Cabinet seat share of leftwing } \\
\text { parties }\end{array}$ & no \\
\hline Bawn and Rosenbluth (2006) & Overall (\% of GDP, levels) & $+/ 0$ & $1970-1998$ & 17 (EU) & $\begin{array}{c}\text { CMP weighted with cabinet seat } \\
\text { shares }\end{array}$ & no \\
\hline Bräuninger (2005) & $\begin{array}{l}\text { Total government expenditure } \\
\text { (\% of GDP, changes) }\end{array}$ & 0 & 1971-1999 & 19 & $\begin{array}{l}\text { CMP (government and } \\
\text { administrative efficiency; need } \\
\text { for efficiency and economy in } \\
\text { government and administration) }\end{array}$ & yes \\
\hline
\end{tabular}




\begin{tabular}{|c|c|c|c|c|c|c|}
\hline Study & Influence on & Effect (leftwing) & Time period & \# countries & Ideology measure & $\begin{array}{l}\text { Ideology } \\
\text { main expl var }\end{array}$ \\
\hline Bräuninger (2005) & $\begin{array}{l}\text { Social security expenditure as a } \\
\text { share of social security } \\
\text { expenditure and economic } \\
\text { affairs }\end{array}$ & 0 & 1971-1999 & 19 & $\begin{array}{l}\text { CMP (government and } \\
\text { administrative efficiency; need } \\
\text { for efficiency and economy in } \\
\text { government and administration) }\end{array}$ & yes \\
\hline Kittel and Winner (2005) & $\begin{array}{l}\text { Total (\% of GDP, first } \\
\text { differences) }\end{array}$ & 0 & 1961-1993 & 17 & $\begin{array}{l}\text { Cabinet seat share of individual } \\
\text { parties, Hicks and Swank 1992, } \\
\text { Huber et al. } 1993\end{array}$ & yes \\
\hline Plümper et al. (2005) & $\begin{array}{l}\text { Total (\% of GDP, first } \\
\text { differences) }\end{array}$ & 0 & 1961-1993 & 17 & $\begin{array}{l}\text { Cabinet seat share of individual } \\
\text { parties, Hicks and Swank 1992, } \\
\text { Huber et al. } 1993\end{array}$ & yes \\
\hline Kittel and Obinger (2003) & Social (\% of GDP, growth) & $0 /+$ & $1982-1997$ & 21 & $\begin{array}{l}\text { Cabinet seat share of individual } \\
\text { parties; Schmidt et al. (2000) }\end{array}$ & yes \\
\hline Perotti and Kontopoulos (2002) & $\begin{array}{l}\text { Primary expenditure (\% of } \\
\text { GDP, changes) }\end{array}$ & $+/ 0$ & 1970-1995 & 19 & Woldendorp et al. & no \\
\hline Perotti and Kontopoulos (2002) & Transfers (\% of GDP, changes) & $+/ 0$ & 1970-1995 & 19 & Woldendorp et al. & no \\
\hline Perotti and Kontopoulos (2002) & $\begin{array}{l}\text { Wage government } \\
\text { consumption (\% of GDP, } \\
\text { changes) }\end{array}$ & 0 & 1970-1995 & 19 & Woldendorp et al. & no \\
\hline Perotti and Kontopoulos (2002) & $\begin{array}{l}\text { Non-wage government } \\
\text { consumption (\% of GDP, } \\
\text { changes) }\end{array}$ & 0 & 1970-1995 & 19 & Woldendorp et al. & no \\
\hline Perotti and Kontopoulos (2002) & $\begin{array}{l}\text { Government investment (\% of } \\
\text { GDP, changes) }\end{array}$ & 0 & 1970-1995 & 19 & Woldendorp et al. & no \\
\hline Garrett and Mitchell (2001) & Total (\% of GDP, levels) & - & 1961-1993 & 18 & $\begin{array}{c}\text { Cabinet seat share of individual } \\
\text { parties, Hicks and Swank 1992, } \\
\text { Huber et al. } 1993\end{array}$ & yes \\
\hline Garrett and Mitchell (2001) & $\begin{array}{l}\text { Government consumption (\% } \\
\text { of GDP, levels) }\end{array}$ & $\begin{array}{c}0 \text { (left) } \\
-(\text { Christian })\end{array}$ & 1961-1993 & 18 & $\begin{array}{c}\text { Cabinet seat share of individual } \\
\text { parties, Hicks and Swank 1992, } \\
\text { Huber et al. } 1993\end{array}$ & yes \\
\hline Garrett and Mitchell (2001) & $\begin{array}{l}\text { Social security transfers (\% of } \\
\text { GDP, levels) }\end{array}$ & 0 & 1961-1993 & 18 & $\begin{array}{l}\text { Cabinet seat share of individual } \\
\text { parties, Hicks and Swank 1992, } \\
\text { Huber et al. } 1993\end{array}$ & yes \\
\hline Boix (1997b) & $\begin{array}{l}\text { Total expenditure (\% of GDP, } \\
\text { levels) }\end{array}$ & - & $\begin{array}{c}1970-1990 \\
\text { (cross-sections } \\
\text { 1970s and 1980s }\end{array}$ & 18 & $\begin{array}{l}\text { Cabinet seat share of individual } \\
\text { parties; }\end{array}$ & yes \\
\hline Cusack (1997) & $\begin{array}{l}\text { Overall expenditure (\% of } \\
\text { GDP, change) }\end{array}$ & $\begin{array}{l}+ \\
+\end{array}$ & $\begin{array}{l}1961-1989 \\
1955-1989\end{array}$ & $\begin{array}{l}16 \\
15\end{array}$ & Cusack’s CoG & yes \\
\hline
\end{tabular}




\begin{tabular}{|c|c|c|c|c|c|c|}
\hline Study & Influence on & Effect (leftwing) & Time period & \# countries & Ideology measure & $\begin{array}{c}\text { Ideology } \\
\text { main expl var }\end{array}$ \\
\hline De Haan and Sturm (1997) & Overall (\% of GDP, change) & 0 & 1982-1992 & 21 & $\begin{array}{c}\text { Cabinet seat shares of leftwing } \\
\text { parties }\end{array}$ & no \\
\hline De Haan and Sturm (1994) & Overall (\% of GDP, change) & + & 1981-1989 & $12(\mathrm{EU})$ & $\begin{array}{l}\text { Cabinet or parliamentary seat } \\
\text { shares of leftwing parties }\end{array}$ & no \\
\hline Schmidt (1997) & Social (\% of GDP, levels) & $\begin{array}{c}\text { + (for left, center and liberal } \\
\text { parties!) }\end{array}$ & 1960-1992 & 18 & $\begin{array}{l}\text { Cabinet seat share of individual } \\
\text { parties }\end{array}$ & no \\
\hline Blais et al. (1993) & $\begin{array}{l}\text { Overall expenditure (\% of } \\
\text { GDP, levels) }\end{array}$ & $+/ 0$ & 1960-1987 & 15 & $\begin{array}{l}\text { Difference between the } \\
\text { percentages of seats of leftwing } \\
\text { and rightwing parties in cabinet }\end{array}$ & yes \\
\hline Huber et al. (1993) & $\begin{array}{l}\text { Social security benefits (\% of } \\
\text { GDP, levels) }\end{array}$ & + & 1956-1986 & 17 & $\begin{array}{c}\text { Cabinet seat shares of leftwing } \\
\text { and religious parties, Castles and } \\
\text { Mair (1984) }\end{array}$ & yes \\
\hline Huber et al. (1993) & $\begin{array}{l}\text { Social security transfer } \\
\text { payments (\% of GDP, levels) }\end{array}$ & + & 1956-1988 & 17 & $\begin{array}{c}\text { Cabinet seat shares of leftwing } \\
\text { and religious parties, Castles and } \\
\text { Mair (1984) }\end{array}$ & yes \\
\hline Hicks and Swank (1992) & Social (\% of GDP, levels) & + & 1960-1982 & 18 & $\begin{array}{c}\text { 4-year averaged share of an } \\
\text { individual party leading } \\
\text { government, Castles and Mair } \\
\text { (1984) }\end{array}$ & no \\
\hline \multicolumn{7}{|l|}{ Taxes } \\
\hline Angelopoulos et al. (2012) & $\begin{array}{l}\text { Labor income to capital income } \\
\text { taxation (ratio), effective tax } \\
\text { rates }\end{array}$ & $-/ 0$ & $1970-2000$ & 16 & $\begin{array}{c}\text { Budge et al. (1993) and } \\
\text { Woldendorp et al. (1998); } \\
\text { Tavares (2004); Castles and Mair } \\
\text { (1984), Cusack (1997) }\end{array}$ & yes \\
\hline Angelopoulos et al. (2012) & $\begin{array}{l}\text { Labor income taxation (levels), } \\
\text { effective tax rates }\end{array}$ & 0 & $1970-2000$ & 16 & $\begin{array}{c}\text { Budge et al. (1993) and } \\
\text { Woldendorp et al. (1998); } \\
\text { Tavares (2004); Castles and Mair } \\
\text { (1984), Cusack (1997) }\end{array}$ & yes \\
\hline Angelopoulos et al. (2012) & $\begin{array}{l}\text { Capital income taxation } \\
\text { (levels), effective tax rates }\end{array}$ & $+/ 0$ & $1970-2000$ & 16 & $\begin{array}{c}\text { Budge et al. (1993) and } \\
\text { Woldendorp et al. (1998); } \\
\text { Tavares (2004); Castles and Mair } \\
\text { (1984), Cusack (1997) }\end{array}$ & yes \\
\hline Angelopoulos et al. (2012) & $\begin{array}{l}\text { Consumption taxation (levels), } \\
\text { effective tax rates }\end{array}$ & + & $1970-2000$ & 16 & $\begin{array}{c}\text { Budge et al. (1993) and } \\
\text { Woldendorp et al. (1998); } \\
\text { Tavares (2004); Castles and Mair } \\
\text { (1984), Cusack (1997) }\end{array}$ & yes \\
\hline
\end{tabular}




\begin{tabular}{|c|c|c|c|c|c|c|}
\hline Study & Influence on & Effect (leftwing) & Time period & \# countries & Ideology measure & $\begin{array}{c}\text { Ideology } \\
\text { main expl var }\end{array}$ \\
\hline Osterloh and Debus (2012) & $\begin{array}{l}\text { Statuary corporate income tax } \\
\text { rates (levels and changes) }\end{array}$ & $\begin{array}{c}+/ 0 \text { (CMP) } \\
0 \text { (Beck et al. 2001) }\end{array}$ & 1980-2006 & 32 (Europe) & $\begin{array}{c}\text { CMP (left-right, economic and } \\
\text { societal, welfare state, market } \\
\text { liberalism), } \\
\text { Beck et al. (2001) }\end{array}$ & yes \\
\hline Osterloh and Debus (2012) & $\begin{array}{l}\text { Effective tax rates (levels and } \\
\text { changes) }\end{array}$ & $\begin{array}{c}\text { +/0 (CMP) } \\
0 \text { (Beck et al. 2001) }\end{array}$ & $1980-2006$ & 32 (Europe) & $\begin{array}{c}\text { CMP (left-right, economic and } \\
\text { societal, welfare state, market } \\
\text { liberalism), } \\
\text { Beck et al. (2001) }\end{array}$ & yes \\
\hline Plümper et al. (2009) & $\begin{array}{l}\text { Average effective tax rates on } \\
\text { capital }\end{array}$ & $\begin{array}{c}+ \text { (left) } \\
0 \text { (Christian) }\end{array}$ & $1975-2004$ & 23 & $\begin{array}{l}\text { Cabinet seat shares of leftwing } \\
\text { and Christian parties, Swank }\end{array}$ & no \\
\hline Plümper et al. (2009) & $\begin{array}{l}\text { Average effective tax rates on } \\
\text { labor }\end{array}$ & 0 & $1975-2004$ & 23 & $\begin{array}{l}\text { Cabinet seat shares of leftwing } \\
\text { and Christian parties, Swank }\end{array}$ & no \\
\hline Plümper et al. (2009) & $\begin{array}{l}\text { Average effective tax rates } \\
\text { ratio labor/capital }\end{array}$ & $\begin{array}{c}-/ 0 \text { (left) } \\
0 \text { (Christian) }\end{array}$ & $1975-2004$ & 23 & $\begin{array}{l}\text { Cabinet seat shares of leftwing } \\
\text { and Christian parties, Swank }\end{array}$ & no \\
\hline Sakamoto (2008) & $\begin{array}{l}\text { Individual income tax revenues } \\
\text { (\% of GDP, levels) }\end{array}$ & 0 (left), - (right) & 1961-2001 & 18 & $\begin{array}{l}\text { Cabinet seat shares of rightwing, } \\
\text { center and leftwing parties, } \\
\text { Armingeon et al. }\end{array}$ & yes \\
\hline Sakamoto (2008) & $\begin{array}{l}\text { Corporate income tax revenues } \\
\text { (\% of GDP, levels) }\end{array}$ & - (left), +/0 (center) & $1961-2001$ & 18 & $\begin{array}{l}\text { Cabinet seat shares of rightwing, } \\
\text { center and leftwing parties, } \\
\text { Armingeon et al. }\end{array}$ & yes \\
\hline Sakamoto (2008) & $\begin{array}{l}\text { Consumption tax revenues (\% } \\
\text { of GDP, levels) }\end{array}$ & + (left), -/0 (center) & 1961-2001 & 18 & $\begin{array}{l}\text { Cabinet seat shares of rightwing, } \\
\text { center and leftwing parties, } \\
\text { Armingeon et al. }\end{array}$ & yes \\
\hline Sakamoto (2008) & $\begin{array}{l}\text { Social security contributions } \\
\text { (\% of GDP, levels) }\end{array}$ & - (left), + (right), 1961-1981 & $1961-2001$ & 18 & $\begin{array}{l}\text { Cabinet seat shares of rightwing, } \\
\text { center and leftwing parties, } \\
\text { Armingeon et al. }\end{array}$ & yes \\
\hline Sakamoto (2008) & $\begin{array}{l}\text { Total government revenues (\% } \\
\text { of GDP, levels) }\end{array}$ & 0 & $1961-2001$ & 18 & $\begin{array}{l}\text { Cabinet seat shares of rightwing, } \\
\text { center and leftwing parties, } \\
\text { Armingeon et al. }\end{array}$ & yes \\
\hline Cusack and Beramendi (2006) & $\begin{array}{l}\text { Average effective tax rates on } \\
\text { labour (five year averages) }\end{array}$ & + & 1965-1995 & 14 & Cabinet and Legislative CoG & yes \\
\hline Beramendi and Rueda (2007) & $\begin{array}{l}\text { Average effective tax rates on } \\
\text { average household } \\
\text { consumption (five year } \\
\text { averages) }\end{array}$ & + & 1965-1995 & 16 & $\begin{array}{c}\text { Cabinet seat shares of social } \\
\text { democratic parties, Armingeon et } \\
\text { al. }\end{array}$ & no \\
\hline Perotti and Kontopoulos (2002) & $\begin{array}{l}\text { Primary government revenues } \\
\text { (\% of GDP, changes) }\end{array}$ & 0 & 1970-1995 & 19 & Woldendorp et al. & no \\
\hline
\end{tabular}




\begin{tabular}{|c|c|c|c|c|c|c|}
\hline Study & Influence on & Effect (leftwing) & Time period & \# countries & Ideology measure & $\begin{array}{l}\text { Ideology } \\
\text { main expl var }\end{array}$ \\
\hline Garrett and Mitchell (2001) & $\begin{array}{l}\text { Effective rate of capital } \\
\text { taxation }\end{array}$ & $\begin{array}{c}0 \text { (left) } \\
+(\text { Christian })\end{array}$ & 1967-1992 & 18 & $\begin{array}{l}\text { Cabinet seat share of individual } \\
\text { parties, Hicks and Swank 1992, } \\
\text { Huber et al. } 1993\end{array}$ & yes \\
\hline Garrett and Mitchell (2001) & $\begin{array}{l}\text { Effective rate of capital } \\
\text { taxation relative to the effective } \\
\text { rates of consumption and labor } \\
\text { taxes }\end{array}$ & $\begin{array}{c}0 \text { (left) } \\
+(\text { Christian)- }\end{array}$ & 1967-1992 & 18 & $\begin{array}{c}\text { Cabinet seat share of individual } \\
\text { parties, Hicks and Swank 1992, } \\
\text { Huber et al. } 1993\end{array}$ & yes \\
\hline Huber et al. (1993) & $\begin{array}{l}\text { Total revenue (\% of GDP, } \\
\text { levels) }\end{array}$ & + & $1960-1988$ & 17 & $\begin{array}{c}\text { Cabinet seat shares of leftwing } \\
\text { and religious parties, Castles and } \\
\text { Mair (1984) }\end{array}$ & yes \\
\hline \multicolumn{7}{|l|}{ Deficits and debt } \\
\hline Hayo and Neumeier (2016) & Primary deficit (\% of GDP) & 0 & $1980-2008$ & 21 & Beck et al. (2001) & no \\
\hline Müller et al. (2016) & Debt-to-GDP-ratio (changes) & $0 /-$ & $1950-2010$ & 24 & Woldendorp et al. & yes \\
\hline Reischmann (2016) & $\begin{array}{l}\text { Stock-flow adjustments (\% of } \\
\text { GDP, changes) }\end{array}$ & $-/ 0$ & $1970-2011$ & 27 & Potrafke (2009a) & no \\
\hline Moessinger (2014) & Debt-to-GDP-ratio (changes) & 0 & $1980-2010$ & 15 & Woldendorp et al. & no \\
\hline Sakamoto (2008) & $\begin{array}{l}\text { Primary balance (\% of GDP, } \\
\text { levels) }\end{array}$ & 0; - (right 1961-1982) & $1961-2001$ & 18 & $\begin{array}{l}\text { Cabinet seat shares of rightwing, } \\
\text { center and leftwing parties, } \\
\text { Armingeon et al. }\end{array}$ & yes \\
\hline Castro (2007) & $\begin{array}{l}\text { Deficits larger than } 3 \% \text { of } \\
\text { GDP }\end{array}$ & + & $1970-2006$ & $15(\mathrm{EU})$ & $\begin{array}{l}\text { Dummy variable for leftwing } \\
\text { governments, Armingeon et al. }\end{array}$ & no \\
\hline Mierau et al. (2007) & $\begin{array}{l}\text { Rapid fiscal adjustments } \\
\text { (binary dependent variable) }\end{array}$ & 0 & $1970-2003$ & 20 & $\begin{array}{l}\text { Indicator assuming values } \\
\text { between } 1 \text { (left) and } 10 \text { (right) }\end{array}$ & no \\
\hline Mierau et al. (2007) & $\begin{array}{l}\text { Gradual fiscal adjustments } \\
\text { (binary dependent variable) }\end{array}$ & 0 & $1970-2003$ & 20 & $\begin{array}{l}\text { Indicator assuming values } \\
\text { between } 1 \text { (left) and } 10 \text { (right) }\end{array}$ & no \\
\hline Tavares (2004) & $\begin{array}{l}\text { Dummy variable for successful } \\
\text { budget consolidation }\end{array}$ & $+/-$ & 1960-1995 & 19 & $\begin{array}{l}\text { Budget et al. (1993), } \\
\text { Woldendorp et al. (1998) } \\
\text { Castles and Mair (1994) } \\
\text { Laver and Hunt (1992) } \\
\text { Warwick (1994) }\end{array}$ & yes \\
\hline Perotti and Kontopoulos (2002) & Deficit (\% of GDP, changes) & 0 & 1970-1995 & 19 & Woldendorp et al. & no \\
\hline Cusack (2001) & Net lending (\% of GDP) & - & 1961-1994 & 16 & Cusack’s CoG & yes \\
\hline Volkerink and de Haan (2001) & Budget deficit (\% of GDP) & + (in the 1970s) & 1971-1996 & 22 & Woldendorp et al. $(1993,1998)$ & no \\
\hline Boix (2000) & debt (\% of GDP, change) & $+/ 0$ & $1962-1993$ & 19 & $\begin{array}{c}\text { Cabinet seat shares of leftwing } \\
\text { parties }\end{array}$ & yes \\
\hline Cusack (1999) & Net lending (\% of GDP) & - & 1961-1991 & 14 & Cusack’s CoG & yes \\
\hline
\end{tabular}




\begin{tabular}{|c|c|c|c|c|c|c|}
\hline Study & Influence on & Effect (leftwing) & Time period & \# countries & Ideology measure & $\begin{array}{c}\text { Ideology } \\
\text { main expl var }\end{array}$ \\
\hline \multirow[t]{2}{*}{ Carlsen (1997) } & Structural deficit (\% of GDP) & + (with high unemployment & 1980-1992 & 18 & Self-compiled assuming & yes \\
\hline & $\begin{array}{l}\text { Nonadjusted deficit (\% of } \\
\text { GDP) }\end{array}$ & for both y) & 1980-1992 & 18 & categorical values from 1 to 5 & \\
\hline Alesina et al. (1997) & Debt-to-GDP-ratio (changes) & 0 & 1961-1993 & 13 & $\begin{array}{c}\text { Dummy for leftwing } \\
\text { governments }\end{array}$ & yes \\
\hline De Haan and Sturm (1994) & Debt-to-GDP-ratio (changes) & 0 & 1981-1989 & $12(\mathrm{EU})$ & $\begin{array}{l}\text { Cabinet or parliamentary seat } \\
\text { shares of leftwing parties }\end{array}$ & no \\
\hline Alesina et al. (1993) & Debt-to-GDP-ratio (changes) & + & $\begin{array}{c}1964-1985 \\
\text { (unbalanced } \\
\text { panel) }\end{array}$ & 13 & $\begin{array}{c}\text { Dummy for leftwing } \\
\text { governments }\end{array}$ & yes \\
\hline \multicolumn{7}{|l|}{ Privatization and regulation } \\
\hline Jäger (2016) & $\begin{array}{l}\text { Modified Economic Freedom } \\
\text { Index (first difference) }\end{array}$ & - & $2000-2012$ & 28 & Armingeon et al. (2014) & yes \\
\hline Smith and Urpelainen (2016) & $\begin{array}{l}\text { Product market regulation } \\
\text { (overall), levels }\end{array}$ & $\begin{array}{c}\text { (with fragmented } \\
\text { legislature) }\end{array}$ & $1978-2007$ & 29 & $\begin{array}{c}\text { Dummy variables based on Beck } \\
\text { et al. (2001) and Potrafke } \\
\text { (2009a) }\end{array}$ & yes \\
\hline Smith and Urpelainen (2016) & $\begin{array}{l}\text { Product market regulation } \\
\text { (airlines), levels }\end{array}$ & 0 & 1978-2007 & 29 & $\begin{array}{l}\text { Dummy variables based on Beck } \\
\text { et al. (2001) and Potrafke } \\
\text { (2009a) }\end{array}$ & yes \\
\hline Smith and Urpelainen (2016) & $\begin{array}{l}\text { Product market regulation } \\
\text { (electricity), levels }\end{array}$ & 0 & $1978-2007$ & 29 & $\begin{array}{c}\text { Dummy variables based on Beck } \\
\text { et al. (2001) and Potrafke } \\
\text { (2009a) }\end{array}$ & yes \\
\hline Smith and Urpelainen (2016) & $\begin{array}{l}\text { Product market regulation } \\
\text { (gas), levels }\end{array}$ & $\begin{array}{c}+ \text { (with fragmented } \\
\text { legislature) }\end{array}$ & $1978-2007$ & 29 & $\begin{array}{c}\text { Dummy variables based on Beck } \\
\text { et al. (2001) and Potrafke } \\
\text { (2009a) }\end{array}$ & yes \\
\hline Smith and Urpelainen (2016) & $\begin{array}{l}\text { Product market regulation } \\
\text { (post), levels }\end{array}$ & $\begin{array}{c}\text { - (with fragmented } \\
\text { legislature) }\end{array}$ & 1978-2007 & 29 & $\begin{array}{l}\text { Dummy variables based on Beck } \\
\text { et al. (2001) and Potrafke } \\
\text { (2009a) }\end{array}$ & yes \\
\hline Smith and Urpelainen (2016) & $\begin{array}{l}\text { Product market regulation } \\
\text { (rail), levels }\end{array}$ & $\begin{array}{c}+ \text { (with fragmented } \\
\text { legislature) }\end{array}$ & 1978-2007 & 29 & $\begin{array}{c}\text { Dummy variables based on Beck } \\
\text { et al. (2001) and Potrafke } \\
\text { (2009a) }\end{array}$ & yes \\
\hline Smith and Urpelainen (2016) & $\begin{array}{l}\text { Product market regulation } \\
\text { (road), levels }\end{array}$ & 0 & $1978-2007$ & 29 & $\begin{array}{l}\text { Dummy variables based on Beck } \\
\text { et al. (2001) and Potrafke } \\
\text { (2009a) }\end{array}$ & yes \\
\hline Smith and Urpelainen (2016) & $\begin{array}{l}\text { Product market regulation } \\
\text { (telecom), levels }\end{array}$ & $\begin{array}{c}\text { (with fragmented } \\
\text { legislature) }\end{array}$ & 1978-2007 & 29 & $\begin{array}{l}\text { Dummy variables based on Beck } \\
\text { et al. (2001) and Potafke (2009a) }\end{array}$ & yes \\
\hline
\end{tabular}




\begin{tabular}{|c|c|c|c|c|c|c|}
\hline Study & Influence on & Effect (leftwing) & Time period & \# countries & Ideology measure & $\begin{array}{c}\text { Ideology } \\
\text { main expl var }\end{array}$ \\
\hline Belloc et al. (2014) & $\begin{array}{l}\text { Privatization and product } \\
\text { market deregulation indicators } \\
\text { (Conway and Nicoletti 2006) }\end{array}$ & +/-(leftwing and rightwing) & $1975-2007$ & 30 & $\begin{array}{l}\text { Beck et al. (2001), dummies for } \\
\text { leftwing and rightwing } \\
\text { governments }\end{array}$ & yes \\
\hline Galasso (2014) & $\begin{array}{l}\text { Product market regulation } \\
\text { indicators (Conway and } \\
\text { Nicoletti 2006) }\end{array}$ & + & $1975-2008$ & 25 & $\begin{array}{l}\text { Beck et al. (2001), dummy for } \\
\text { rightwing and center } \\
\text { governments }\end{array}$ & yes \\
\hline Galasso (2014) & $\begin{array}{l}\text { Public ownership (Conway and } \\
\text { Nicoletti 2006) }\end{array}$ & + & $1975-2008$ & 25 & $\begin{array}{l}\text { Beck et al. (2001), dummy for } \\
\text { rightwing and center } \\
\text { governments }\end{array}$ & yes \\
\hline Galasso (2014) & Financial market regulation & $0 /-$ & $1973-2005$ & 23 & $\begin{array}{l}\text { Beck et al. (2001), dummy for } \\
\text { rightwing and center } \\
\text { governments }\end{array}$ & yes \\
\hline Galasso (2014) & $\begin{array}{l}\text { Employment protection } \\
\text { legislation }\end{array}$ & $0 /+$ & $1985-2008$ & 23 & $\begin{array}{l}\text { Beck et al. (2001), dummy for } \\
\text { rightwing and center } \\
\text { governments }\end{array}$ & yes \\
\hline Galasso (2014) & Unemployment benefits & $+/ 0$ & $1975-2007$ & 23 & $\begin{array}{l}\text { Beck et al. (2001), dummy for } \\
\text { rightwing and center } \\
\text { governments }\end{array}$ & yes \\
\hline Galasso (2014) & Retirement incentives & 0 & $1985-2003$ & 20 & $\begin{array}{l}\text { Beck et al. (2001), dummy for } \\
\text { rightwing and center } \\
\text { governments }\end{array}$ & yes \\
\hline Obinger et al. (2014) & $\begin{array}{l}\text { Privatization index (turnover of } \\
\text { public enterprises in \% of } \\
\text { GDP) }\end{array}$ & - & $1980-2007$ & 20 & $\begin{array}{l}\text { Cabinet seat share of individual } \\
\text { parties; ideological position by } \\
\text { Döring and Manow }\end{array}$ & yes \\
\hline Wiese (2014) & Health sector privatization & 0 & $1960-2010$ & 23 & Potrafke & no \\
\hline Bortolotti et al. (2013) & $\begin{array}{l}\text { Ultimate control rights of the } \\
\text { government over firms }\end{array}$ & $+/ 0$ & 1994-2005 & $\begin{array}{l}15 \text { EU, all } \\
\text { OECD } \\
\text { member }\end{array}$ & $\begin{array}{c}\text { Weighted average of the } \\
\text { ideologies of the governing } \\
\text { parties (Huber and Inglehart } \\
\text { 1995), updated by Bortolotti and } \\
\text { Pinotti (2008) }\end{array}$ & no \\
\hline Bortolotti et al. (2013) & $\begin{array}{l}\text { Independent Regulatory } \\
\text { Authorities established }\end{array}$ & - & 1994-2005 & $\begin{array}{l}15 \text { EU, all } \\
\text { OECD } \\
\text { member }\end{array}$ & $\begin{array}{l}\text { Weighted average of the } \\
\text { ideologies of the governing } \\
\text { parties (Huber and Inglehart } \\
\text { 1995), updated by Bortolotti and } \\
\text { Pinotti (2008) }\end{array}$ & no \\
\hline
\end{tabular}




\begin{tabular}{|c|c|c|c|c|c|c|}
\hline Study & Influence on & Effect (leftwing) & Time period & \# countries & Ideology measure & $\begin{array}{l}\text { Ideology } \\
\text { main expl var }\end{array}$ \\
\hline \multirow[t]{2}{*}{ Roberts and Saeed (2012) } & Number of privatization deals, & 0 & $1988-2006$ & 13 & Dummy for rightwing & \multirow[t]{2}{*}{ no } \\
\hline & $\begin{array}{l}\text { Revenue from privatization (\% } \\
\text { of GDP) }\end{array}$ & 0 & 1988-2006 & 13 & government (Beck et al. 2001) & \\
\hline Jensen (2012b) & $\begin{array}{l}\text { Unemployment replacement } \\
\text { rates (changes) }\end{array}$ & 0 & $1980-2002$ & 18 & $\begin{array}{c}\text { Cabinet shares of rightwing } \\
\text { parties; Swank }\end{array}$ & yes \\
\hline Belloc and Nicita (2011) & Network industry liberalization & + /-(leftwing and rightwing) & $1975-2006$ & 30 & $\begin{array}{l}\text { Beck et al. (2001), dummies } \\
\text { based on Potrafke (2009a) and } \\
\text { Armingeon et al. }\end{array}$ & yes \\
\hline Chang and Berdiev (2011) & $\begin{array}{l}\text { Gas industry regulation } \\
\text { (growth rate) }\end{array}$ & + & $1975-2007$ & 23 & $\begin{array}{l}\text { Potrafke (2009a), } \\
\text { Indicator based on Beck et al. } \\
\text { (2001), weighted with parties' } \\
\text { seats in parliament }\end{array}$ & yes \\
\hline Chang and Berdiev (2011) & $\begin{array}{l}\text { Electricity industry regulation } \\
\text { (growth rate) }\end{array}$ & $+/ 0$ & $1975-2007$ & 23 & $\begin{array}{l}\text { Potrafke (2009a), } \\
\text { Indicator based on Beck et al. } \\
\text { (2001), weighted with parties' } \\
\text { seats in parliament }\end{array}$ & yes \\
\hline Duso and Seldelachts (2010) & $\begin{array}{l}\text { Mobile telecommunications } \\
\text { liberalization }\end{array}$ & - & 1991-1997 & 24 & $\begin{array}{l}\text { CMP (regulation, welfare state } \\
\text { expansion), }\end{array}$ & no \\
\hline Potrafke (2010b) & $\begin{array}{l}\text { Regulation of energy, transport, } \\
\text { and communication industries } \\
\text { (ETCR), growth rates }\end{array}$ & + & $1980-2003$ & 21 & $\begin{array}{l}\text { Potrafke (2009a), } \\
\text { Bjørnskov (2008) }\end{array}$ & yes \\
\hline Potrafke (2010b) & $\begin{array}{l}\text { All ETCR but public } \\
\text { ownership }\end{array}$ & $+/ 0$ & $1980-2003$ & 21 & $\begin{array}{l}\text { Potrafke (2009a), } \\
\text { Bjørnskov (2008) }\end{array}$ & yes \\
\hline Potrafke (2010b) & Entry barriers & + & $1980-2003$ & 21 & $\begin{array}{l}\text { Potrafke (2009a), } \\
\text { Bjørnskov (2008) }\end{array}$ & yes \\
\hline Potrafke (2010b) & Public ownership & + & $1980-2003$ & 21 & $\begin{array}{l}\text { Potrafke (2009a), } \\
\text { Bjørnskov (2008) }\end{array}$ & yes \\
\hline Potrafke (2010c) & $\begin{array}{l}\text { Active labor market policy } \\
\text { expenditures }\end{array}$ & 0 & $1982-2003$ & 20 & Potrafke (2009a) & no \\
\hline Potrafke (2010c) & Benefit duration & 0 & $1982-2003$ & 20 & Potrafke (2009a) & no \\
\hline Potrafke (2010c) & $\begin{array}{l}\text { Employment protection } \\
\text { (overall) }\end{array}$ & 0 & $1982-2003$ & 20 & Potrafke (2009a) & no \\
\hline Potrafke (2010c) & $\begin{array}{l}\text { Employment protection } \\
\text { (regularly employed) }\end{array}$ & 0 & $1982-2003$ & 20 & Potrafke (2009a) & no \\
\hline Potrafke (2010c) & $\begin{array}{l}\text { Employment protection } \\
\text { (temporarily employed) }\end{array}$ & 0 & $1982-2003$ & 20 & Potrafke (2009a) & no \\
\hline Potrafke (2010c) & Replacement rate & $0 /+$ & $1982-2003$ & 20 & Potrafke (2009a) & no \\
\hline
\end{tabular}




\begin{tabular}{|c|c|c|c|c|c|c|}
\hline Study & Influence on & Effect (leftwing) & Time period & \# countries & Ideology measure & $\begin{array}{l}\text { Ideology } \\
\text { main expl var }\end{array}$ \\
\hline Potrafke (2010c) & Tax wedge & 0 & 1982-2003 & 20 & Potrafke (2009a) & no \\
\hline Potrafke (2010c) & Union density & + & 1982-2003 & 20 & Potrafke (2009a) & no \\
\hline Bortolotti and Pinotti (2008) & $\begin{array}{l}\text { Increases in total privatization } \\
\text { revenues (\% of GDP) }\end{array}$ & - & $1977-2002$ & 21 & $\begin{array}{c}\text { Weighted average of the } \\
\text { ideologies of the governing } \\
\text { parties (Huber and Inglehart } \\
\text { 1995) }\end{array}$ & no \\
\hline Belke et al. (2007) & $\begin{array}{l}\text { Revenue from privatization (\% } \\
\text { of GDP) }\end{array}$ & - & $1990-2001$ & 22 & $\begin{array}{l}\text { Cabinet shares of individual } \\
\text { parties; Swank }\end{array}$ & no \\
\hline Pitlik (2007) & $\begin{array}{l}\text { Economic Freedom Index } \\
\text { (overall) }\end{array}$ & - & $1970-2000$ & 23 & $\begin{array}{l}\text { Five year averaged cabinet } \\
\text { shares of leftwing parties } \\
\text { (Armingeon et al. 2004) }\end{array}$ & no \\
\hline Pitlik (2007) & $\begin{array}{l}\text { Economic Freedom Index (size } \\
\text { of government) }\end{array}$ & - & $1970-2000$ & 23 & $\begin{array}{l}\text { Five year averaged cabinet } \\
\text { shares of leftwing parties } \\
\text { (Armingeon et al.) }\end{array}$ & no \\
\hline Pitlik (2007) & $\begin{array}{l}\text { Economic Freedom Index } \\
\text { (regulation) }\end{array}$ & $-/ 0$ & $1970-2000$ & 23 & $\begin{array}{l}\text { Five year averaged cabinet } \\
\text { shares of leftwing parties } \\
\text { (Armingeon et al.) }\end{array}$ & no \\
\hline Pitlik (2007) & $\begin{array}{l}\text { Economic Freedom Index } \\
\text { (trade liberalization) }\end{array}$ & 0 & $1970-2000$ & 23 & $\begin{array}{l}\text { Five year averaged cabinet } \\
\text { shares of leftwing parties } \\
\text { (Armingeon et al.) }\end{array}$ & no \\
\hline Pitlik (2007) & $\begin{array}{l}\text { Economic Freedom Index } \\
\text { (monetary policy) }\end{array}$ & + & $1970-2000$ & 23 & $\begin{array}{l}\text { Five year averaged cabinet } \\
\text { shares of leftwing parties } \\
\text { (Armingeon et al.) }\end{array}$ & no \\
\hline Pitlik (2007) & $\begin{array}{l}\text { Economic Freedom Index } \\
\text { (legal structure and security of } \\
\text { property rights) }\end{array}$ & + & $1970-2000$ & 23 & $\begin{array}{l}\text { Five year averaged cabinet } \\
\text { shares of leftwing parties } \\
\text { (Armingeon et al. 2004) }\end{array}$ & no \\
\hline Allan and Scruggs (2004) & $\begin{array}{l}\text { Unemployment replacement } \\
\text { rates (changes) }\end{array}$ & + & 1975-1999 & 18 & $\begin{array}{l}\text { Cabinet shares of individual } \\
\text { parties; Swank }\end{array}$ & yes \\
\hline Allan and Scruggs (2004) & $\begin{array}{l}\text { Sick pay replacement rates } \\
\text { (changes) }\end{array}$ & + & 1975-1999 & 18 & $\begin{array}{c}\text { Cabinet shares of individual } \\
\text { parties; Swank }\end{array}$ & yes \\
\hline Korpi and Palme (2003) & $\begin{array}{l}\text { Introduction of major cuts in } \\
\text { net replacement (sickness, } \\
\text { work accident, unemployment) }\end{array}$ & - & 1976-1995 & 18 & $\begin{array}{l}\text { Cabinet seats shares of leftwing } \\
\text { and rightwing parties }\end{array}$ & yes \\
\hline Duso and Röller (2003) & $\begin{array}{l}\text { Mobile telecommunications } \\
\text { liberalization }\end{array}$ & - & 1993-1997 & 24 & CMP (left-right), & no \\
\hline
\end{tabular}




\begin{tabular}{|c|c|c|c|c|c|c|}
\hline Study & Influence on & Effect (leftwing) & Time period & \# countries & Ideology measure & $\begin{array}{l}\text { Ideology } \\
\text { main expl var }\end{array}$ \\
\hline Boix (1997a) & $\begin{array}{l}\text { Volume of public assets sold } \\
\text { (\%of GDP) } \\
\text { self-compiled index describing } \\
\text { "strategies towards the public } \\
\text { business sector" }\end{array}$ & - & 1979-1992 & $?$ & $\begin{array}{l}\text { Cabinet seat share of individual } \\
\text { parties; index considering party } \\
\text { positions on public control of } \\
\text { ownership }\end{array}$ & yes \\
\hline \multicolumn{7}{|l|}{ Environment and energy } \\
\hline Wen et al. (2016) & $\begin{array}{l}\text { Environmental Performance } \\
\text { Index }\end{array}$ & + & $2002-2012$ & 31 & $\begin{array}{l}\text { Indicator based on party families, } \\
\text { Indicator based on party families } \\
\text { weighted with legislative seats; } \\
\text { Beck et al. (2001); CMP (left- } \\
\text { right, environment protection, } \\
\text { anti-growth economy) }\end{array}$ & yes \\
\hline Wen et al. (2016) & Environmental Health Index & + & $2002-2012$ & 31 & $\begin{array}{l}\text { Indicator based on party families, } \\
\text { Indicator based on party families } \\
\text { weighted with legislative seats; } \\
\text { Beck et al. (2001); CMP (left- } \\
\text { right, environment protection, } \\
\text { anti-growth economy) }\end{array}$ & yes \\
\hline Wen et al. (2016) & Environmental Vitality Index & + & 2002-2012 & 31 & $\begin{array}{l}\text { Indicator based on party families, } \\
\text { Indicator based on party families } \\
\text { weighted with legislative seats; } \\
\text { Beck et al. (2001); CMP (left- } \\
\text { right, environment protection, } \\
\text { anti-growth economy) }\end{array}$ & yes \\
\hline Wen and Chang (2015) & $\begin{array}{l}\text { Natural disaster losses (number } \\
\text { of deaths, levels) }\end{array}$ & 0 & $1975-2013$ & 30 & $\begin{array}{l}\text { Indicator based on party families, } \\
\text { Indicator based on party families } \\
\text { weighted with legislative seats; }\end{array}$ & yes \\
\hline Wen and Chang (2015) & $\begin{array}{l}\text { Natural disaster losses (people } \\
\text { affected, levels) }\end{array}$ & + & $1975-2013$ & 30 & $\begin{array}{l}\text { Indicator based on party families, } \\
\text { Indicator based on party families } \\
\text { weighted with legislative seats; }\end{array}$ & yes \\
\hline Wen and Chang (2015) & $\begin{array}{l}\text { Natural disaster losses } \\
\text { (damages, levels) }\end{array}$ & 0 & $1975-2013$ & 30 & $\begin{array}{l}\text { Indicator based on party families, } \\
\text { Indicator based on party families } \\
\text { weighted with legislative seats; }\end{array}$ & yes \\
\hline Garmann (2014) & $\begin{array}{l}\text { Air pollution: carbon dioxide } \\
\text { emissions per unit GDP, } \\
\text { growth rates }\end{array}$ & - & $1992-2008$ & 19 & Woldendorp et al. & yes \\
\hline
\end{tabular}




\begin{tabular}{|c|c|c|c|c|c|c|}
\hline Study & Influence on & Effect (leftwing) & Time period & \# countries & Ideology measure & $\begin{array}{c}\text { Ideology } \\
\text { main expl var }\end{array}$ \\
\hline Schulze (2014) & $\begin{array}{l}\text { Ratifying international } \\
\text { environment agreements } \\
\text { (IEAs) }\end{array}$ & $\begin{array}{c}+ \text { (CMP environment } \\
\text { protection }) \\
0\end{array}$ & $1971-2003$ & 21 & $\begin{array}{l}\text { CMP (environment protection, } \\
\text { left-right) }\end{array}$ & yes \\
\hline Aklin and Urpelainen (2013) & $\begin{array}{l}\text { Share of renewable in } \\
\text { electricity generation capacity } \\
\text { (growth rate). }\end{array}$ & $+/ 0$ & $1989-2008$ & 28 & $\begin{array}{c}\text { Beck et al. (2001); } \\
\text { CMP (environment protection } \\
\text { and regulation) }\end{array}$ & no \\
\hline Cheon and Urpelainen (2013) & $\begin{array}{l}\text { Share of non-hydro renewable } \\
\text { in electricity generation } \\
\text { capacity (first difference). }\end{array}$ & 0/- (green parties) & $1989-2007$ & 19 & $\begin{array}{c}\text { Beck et al. (2001); } \\
\text { CMP (environment protection) }\end{array}$ & no \\
\hline Jensen and Spoon (2011) & $\begin{array}{l}\text { Distance to the greenhouse gas } \\
\text { emissions target (change) }\end{array}$ & - & $1998-2003$ & 15 & $\begin{array}{l}\text { CMP (left-right, environmental } \\
\text { protection }\end{array}$ & yes \\
\hline Knill et al. (2010) & ENVIPOLCON & + & $1970-2000$ & 18 & $\begin{array}{l}\text { CMP (environment protection, } \\
\text { left-right) }\end{array}$ & yes \\
\hline Neumayer (2003) & $\begin{array}{l}\text { Air pollution: sulphur dioxide } \\
\text { emissions per capita }\end{array}$ & $-/ 0$ & 1980-1999 & 18 & $\begin{array}{l}\text { Share of green or left-libertarian } \\
\text { parties in parliament, leftwing } \\
\text { parties, and share of cabinet } \\
\text { seats; Swank (2002) }\end{array}$ & yes \\
\hline Neumayer (2003) & $\begin{array}{l}\text { Air pollution: carbon monoxide } \\
\text { emissions per capita }\end{array}$ & $+/ 0$ & 1990-1999 & 18 & $\begin{array}{l}\text { Share of green or left-libertarian } \\
\text { parties in parliament, leftwing } \\
\text { parties, and share of cabinet } \\
\text { seats; Swank (2002) }\end{array}$ & yes \\
\hline Neumayer (2003) & $\begin{array}{l}\text { Air pollution: carbon dioxide } \\
\text { emissions per capita }\end{array}$ & $+/ 0 /-$ & 1980-1999 & 21 & $\begin{array}{l}\text { Share of green or left-libertarian } \\
\text { parties in parliament, leftwing } \\
\text { parties, and share of cabinet } \\
\text { seats; Swank (2002) }\end{array}$ & yes \\
\hline Neumayer (2003) & $\begin{array}{l}\text { Air pollution: nitrogen dioxide } \\
\text { emissions per capita }\end{array}$ & $+/ 0 /-$ & 1980-1999 & 18 & $\begin{array}{l}\text { Share of green or left-libertarian } \\
\text { parties in parliament, leftwing } \\
\text { parties, and share of cabinet } \\
\text { seats; Swank (2002) }\end{array}$ & yes \\
\hline Neumayer (2003) & $\begin{array}{l}\text { Air pollution: volatile organic } \\
\text { compound (VOC) emissions } \\
\text { per capita }\end{array}$ & $+/ 0 /-$ & 1990-1999 & 18 & $\begin{array}{c}\text { Share of green or left-libertarian } \\
\text { parties in parliament, leftwing } \\
\text { parties, and share of cabinet } \\
\text { seats; Swank (2002) }\end{array}$ & yes \\
\hline \multicolumn{7}{|l|}{ Others } \\
\hline Aidt et al. (2016) & $\begin{array}{l}\text { Genuine wealth (per capita, } \\
\text { growth rate) }\end{array}$ & - & $1981-2013$ & 31 & $\begin{array}{l}\text { Dummy variable for leftwing } \\
\text { governments, Beck et al. (2001) }\end{array}$ & yes \\
\hline
\end{tabular}




\begin{tabular}{|c|c|c|c|c|c|c|}
\hline Study & Influence on & Effect (leftwing) & Time period & \# countries & Ideology measure & $\begin{array}{c}\text { Ideology } \\
\text { main expl var }\end{array}$ \\
\hline Castro and Martins (2016b) & $\begin{array}{l}\text { Human Development Index } \\
\text { (HDI), growth rate }\end{array}$ & 0 & $1980-2013$ & 34 & $\begin{array}{l}\text { Dummy variable for leftwing } \\
\text { governments, Beck et al. (2001) }\end{array}$ & yes \\
\hline Filote (2016) & $\begin{array}{l}\text { UNGA voting on disarmament } \\
\text { and reducing nuclear material }\end{array}$ & + & $1975-2012$ & 22 & $\begin{array}{l}\text { Ideology index based on Beck et } \\
\text { al. (2001), Potrafke (2009a) }\end{array}$ & yes \\
\hline Bodea (2015) & $\begin{array}{l}\text { Realignments vis-à-vis the } \\
\text { German currency }\end{array}$ & - & 1979-1993 & 9 & $\begin{array}{l}\text { CMP, center of gravity, common } \\
\text { ideology measure }\end{array}$ & yes \\
\hline Busemeyer (2015) & $\begin{array}{l}\text { Gross enrolment in tertiary } \\
\text { education (change) }\end{array}$ & $\begin{array}{c}\text {-/0 (conservative) } \\
+/ 0 \text { (social democrats) }\end{array}$ & $1971-2008$ & 21 & $\begin{array}{l}\text { Cabinet seat share of individual } \\
\text { parties; Armingeon et al. }\end{array}$ & yes \\
\hline Busemeyer (2015) & $\begin{array}{l}\text { Gross enrolment in tertiary } \\
\text { education (level) }\end{array}$ & +/0 (social democrats) & 1993-2008 & 21 & $\begin{array}{l}\text { Cabinet seat share of individual } \\
\text { parties; Armingeon et al. } \\
\text { Ideology index; Schmidt and } \\
\text { Armingeon et al. }\end{array}$ & yes \\
\hline Busemeyer (2015) & Gini index & $0 /-$ & $1997-2008$ & 19 & $\begin{array}{l}\text { Ideology index; Schmidt and } \\
\text { Armingeon et al. }\end{array}$ & no \\
\hline $\begin{array}{l}\text { Jochimsen and Lehmann } \\
\text { (2016) }\end{array}$ & $\begin{array}{l}\text { Optimistic tax revenue } \\
\text { forecasts }\end{array}$ & + & 1996-2012 & 18 & Schmidt, Potrafke (2009a) & yes \\
\hline Brech and Potrafke (2014) & $\begin{array}{l}\text { Types of foreign aid (\% of } \\
\text { GDP, growth rates, } 53 \text { different } \\
\text { dependent variables) }\end{array}$ & $\begin{array}{l}\text { + for bilateral grant aid, esp. } \\
\text { to LDCs }\end{array}$ & $1960-2009$ & 23 & $\begin{array}{l}\text { Potrafke (2009a), Bjørnskov } \\
\text { (2008) }\end{array}$ & yes \\
\hline Schinke (2014) & $\begin{array}{l}\text { Top 1\% income share } \\
\text { (changes) }\end{array}$ & - & $1970-2010$ & 16 & Potrafke (2009a) & yes \\
\hline Schinke (2014) & $\begin{array}{l}\text { Next 9\% income share } \\
\text { (changes) }\end{array}$ & $0 /-$ & $1970-2010$ & 16 & Potrafke (2009a) & yes \\
\hline Camyar and Ulupinar (2013) & Firm value (Tobin’s Q) & + & $1989-2008$ & 21 & $\begin{array}{l}\text { Cabinet seat shares of individual } \\
\text { parties, Armingeon et al. }\end{array}$ & yes \\
\hline Baumann and Brändle (2012) & Being self-employed & 0 & $1981-2007$ & 23 & Potrafke (2009a) & no \\
\hline Berdiev et al. (2012) & Fixed exchange rate regime & - & 1974-2004 & 26 & Beck et al. (2001) & yes \\
\hline Berdiev et al. (2012) & Flexible exchange rate regime & 0 & $1974-2004$ & 26 & Beck et al. (2001) & yes \\
\hline Caynes-Wrone and Park (2012) & $\begin{array}{l}\text { Private fixed investment } \\
\text { (growth rates) }\end{array}$ & 0 & $1975-2006$ & 10 & Beck et al. (2001) & no \\
\hline Tingley (2010) & $\begin{array}{l}\text { Types of foreign aid (\% of } \\
\text { GDP, first differences, } 3 \\
\text { different dependent variables) }\end{array}$ & + esp. to LDCs & $1971-2002$ & 25 & $\begin{array}{c}\text { First differences of CMP } \\
\text { (economic); cumulative cabinet } \\
\text { seat shares of individual parties }\end{array}$ & yes \\
\hline Potrafke (2009b) & $\begin{array}{l}\text { UNGA voting in line with the } \\
\text { United States }\end{array}$ & - & $1984-2005$ & 21 & $\begin{array}{c}\text { Potrafke (2009a), Bjørnskov } \\
\text { (2008) }\end{array}$ & yes \\
\hline
\end{tabular}




\begin{tabular}{|c|c|c|c|c|c|c|}
\hline Study & Influence on & Effect (leftwing) & Time period & \# countries & Ideology measure & $\begin{array}{c}\text { Ideology } \\
\text { main expl var }\end{array}$ \\
\hline Sakamoto (2008) & $\begin{array}{l}\text { Government employment (\% of } \\
\text { total employment }\end{array}$ & $+/ 0$ & 1961-2001 & 18 & $\begin{array}{l}\text { Cabinet seat shares of rightwing, } \\
\text { center and leftwing parties, } \\
\text { Armingeon et al. }\end{array}$ & yes \\
\hline
\end{tabular}

